\title{
Strengthening Clean Energy Technology Cooperation under the UNFCCC:
}

\section{Steps toward Implementation}

\section{NREL/TP-6A0-48596}

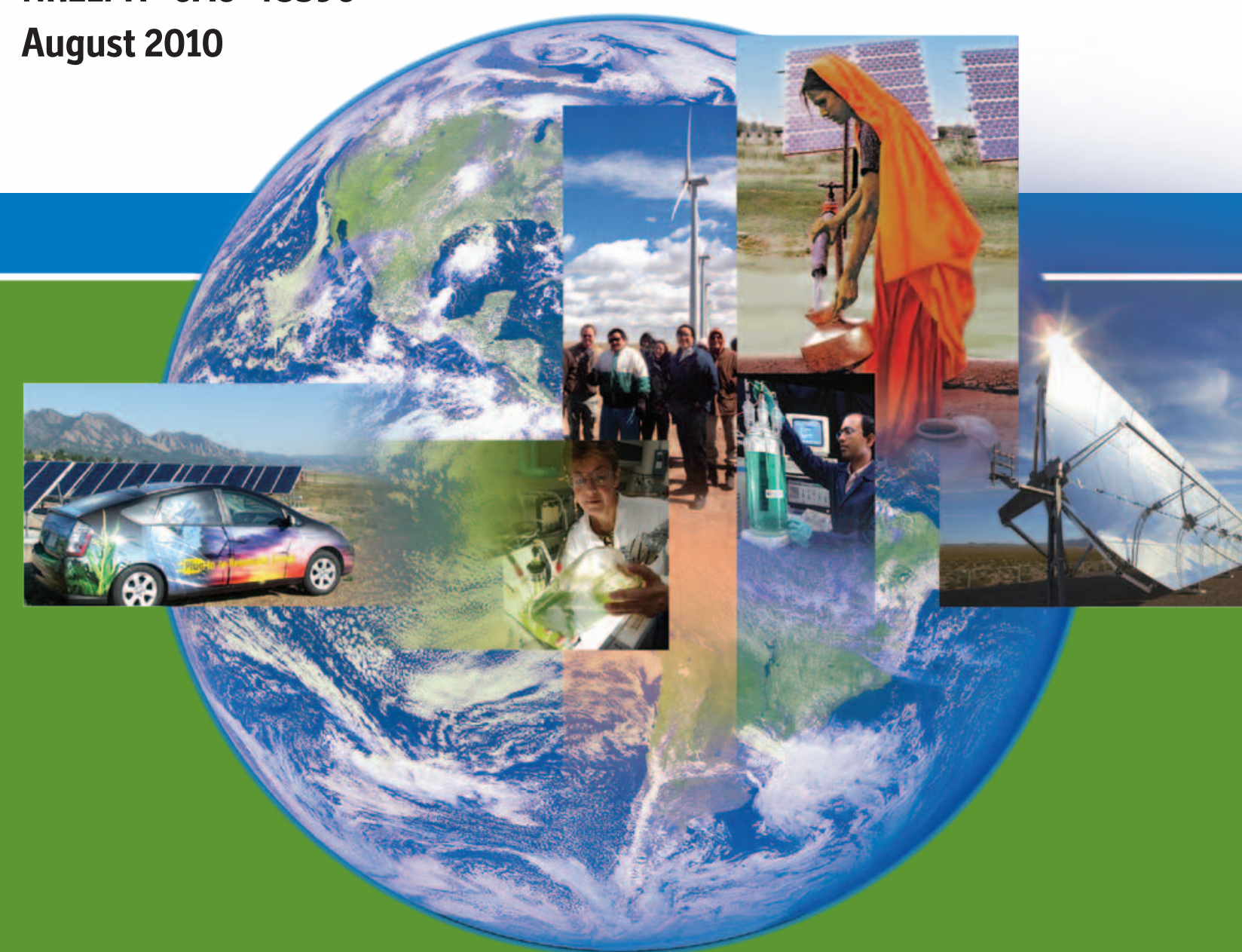

Ron Benioff (NREL), Heleen de Coninck (ECN), Subash Dhar (Risoe National Lab), Ulrich Hansen (Risoe National Lab), Joyce McLaren (NREL), and Jyoti Painuly (Risoe National Lab)

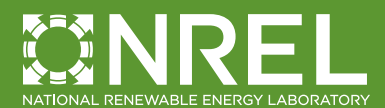

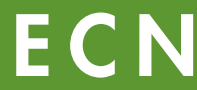

Energy research Centre of the Netherlands
UISEP URO

UNEP RIS $\varnothing$ CENTRE, RIS $\varnothing$ DTU 


\section{NOTICE}

This report was prepared as an account of work sponsored by an agency of the United States government. Neither the United States government nor any agency thereof, nor any of their employees, nor any of their contributors, makes any warranty, express or implied, or assumes any legal liability or responsibility for the accuracy, completeness, or usefulness of any information, apparatus, product, or process disclosed, or represents that its use would not infringe privately owned rights. Reference herein to any specific commercial product, process, or service by trade name, trademark, manufacturer, or otherwise does not necessarily constitute or imply its endorsement, recommendation, or favoring by the United States government or any agency thereof. The views and opinions of authors expressed herein do not necessarily state or reflect those of the United States government or any agency thereof.

Available electronically at http://www.osti.gov/bridge

Available for a processing fee to U.S. Department of Energy and its contractors, in paper, from:

U.S. Department of Energy

Office of Scientific and Technical Information

P.O. Box 62

Oak Ridge, TN 37831-0062

phone: 865.576 .8401

fax: 865.576 .5728

email: mailto:reports@adonis.osti.gov

Available for sale to the public, in paper, from:

U.S. Department of Commerce

National Technical Information Service

5285 Port Royal Road

Springfield, VA 22161

phone: 800.553.6847

fax: 703.605.6900

email: orders@ntis.fedworld.gov

online ordering: http://www.ntis.gov/ordering.htm 


\section{List of Acronyms}

\begin{tabular}{|c|c|}
\hline APP & Asia Pacific Partnership \\
\hline ASEAN & Association of Southeast Asian Nations \\
\hline $\mathrm{CDM}$ & Clean Development Mechanism \\
\hline $\mathrm{COP}$ & Conference of the Parties \\
\hline CTI & Climate Technology Initiative \\
\hline EGTT & Expert Group on Technology Transfer \\
\hline GEF & Global Environment Facility \\
\hline IEA & International Energy Agency \\
\hline IPEEC & International Partnership for Energy Efficiency Cooperation \\
\hline IPR & Intellectual Property Rights \\
\hline IRENA & International Renewable Energy Agency \\
\hline LDCs & Least Developed Countries \\
\hline MEF & Major Economies Forum \\
\hline NAMA & Nationally Appropriate Mitigation Action \\
\hline NEET & Networks of Expertise on Energy Technologies \\
\hline PFAN & Private Financing Advisory Network \\
\hline $\mathrm{R} \& \mathrm{D}$ & Research \& Development \\
\hline RD\&D & Research, Development, and Demonstration \\
\hline RPS & Renewable Portfolio Standard \\
\hline TAP & Technology Action Plan \\
\hline TNA & Technology Needs Assessment \\
\hline UNFCCC & United Nations Framework Convention on Climate Change \\
\hline WEACT & $\begin{array}{l}\text { World-wide Energy Efficiency Action through Capacity Building and } \\
\text { Training }\end{array}$ \\
\hline
\end{tabular}




\section{Executive Summary}

Accelerating the transition to clean energy technologies is critical for addressing international climate stabilization goals and creating a foundation for sustained economic growth. Since the Copenhagen Accord has not led to a global target for greenhouse gas emissions and, as such, gives little guidance to the private sector to deploy clean energy technology, bottom-up, national, and technology-specific policies are gaining importance. Relying on such mechanisms rather than on a global carbon market calls for insights into their effectiveness, applicability, and expected impacts. This study discusses policies directed toward three areas relevant to the development of clean energy technology: the creation of enabling environments, furthering research and development, and the provision of financing.

Table ES-1. Selected International Clean Energy Technology Cooperation Options Evaluated in this Paper

\begin{tabular}{|l|l|l|}
\hline \multicolumn{1}{|c|}{ Research and Development } & \multicolumn{1}{|c|}{ Enabling Environments } & \multicolumn{1}{c|}{ Financing } \\
\hline R\&D networks and road mapping & National policies & $\begin{array}{l}\text { Investment matchmaking and } \\
\text { advisory services }\end{array}$ \\
\hline Multilateral R\&D collaboration & $\begin{array}{l}\text { International cooperation on } \\
\text { sectoral deployment programs }\end{array}$ & Coordination of existing funds \\
\hline $\begin{array}{l}\text { Technology demonstration } \\
\text { partnerships }\end{array}$ & Intellectual property rights & Investment risk mitigation \\
\hline
\end{tabular}

Programs to advance clean energy technology are likely to be most effective if they focus on well defined and broadly endorsed national priorities, strengthen developing country capacity and enabling environments, have sufficient scale, run over multiple years, engage public and private entities, promote broad knowledge sharing, and are coordinated and harmonized with international support.

For R\&D programs, networks could allow for knowledge sharing between researchers, engaging developing country research institutions, and engage practitioners who can increase technology deployment. Work in R\&D programs can be guided by roadmaps that provide direction, advisory groups that monitor progress and provide independent feedback, and implementing agencies that have a long-term commitment towards implementation.

Increased R\&D capabilities are needed in developing and least-developed countries alike. Without the strengthening of such capabilities, the establishment of partnerships, jointinvestments, and R\&D collaborations will remain challenging. Part of a long-term strategy for clean energy technology should therefore be to implement structural programs for capacity building in all phases of the technology innovation chain. Such enabling efforts may need to be sector- or technology-specific, supported by strong national policies and explicitly aimed at improving the investment climate for a technology in a country.

To enable financing of clean energy technology, finance and technology programs need to be aligned - as the type of financing depends on the technology. Experience with finance instruments should inform replication. Experimentation with risk-based models for public finance mechanisms may prove more cost effective along the innovation chain. 
In the post-Copenhagen environment, countries and international organizations may be best served by applying pragmatic approaches that enhance long-term commitment to collaboration through existing bilateral and multilateral partnerships and demonstrate a commitment to rapid scaling up of technology cooperation and financing. 


\section{Table of Contents}

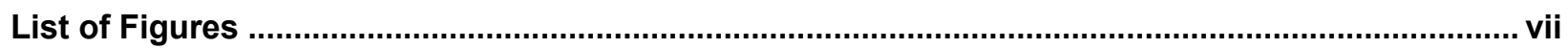

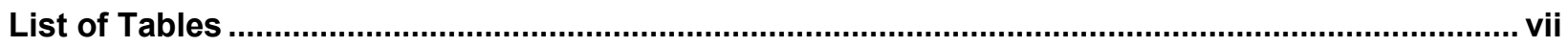

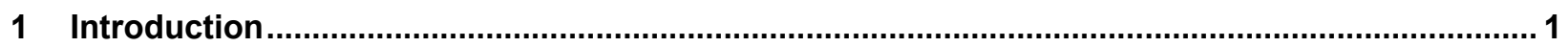

2 Current Implementation Frameworks for Clean Energy Technology Cooperation under the

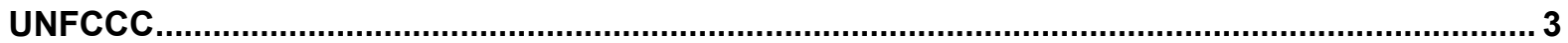

2.1 Current UNFCCC Technology Cooperation Framework ...............................................3

2.2 Summary of Selected International Clean Energy Technology Cooperation Programs......4

2.3 Comparison of Implementation Attributes of Existing Programs ..................................6

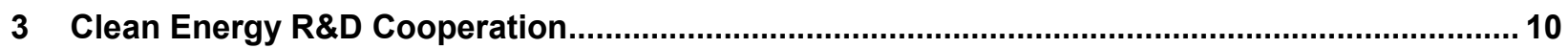

3.1 Role of Global R\&D Cooperation ........................................................................... 10

3.2 Example Structure for R\&D Networks and Road Mapping ........................................ 10

3.3 Example Implementation Structure for Multilateral R\&D Cooperation .........................13

3.4 Example Structure for Technology Demonstration Collaboration ................................... 15

3.5 Potential Integrated R\&D Clean Energy Cooperation Framework ................................ 17

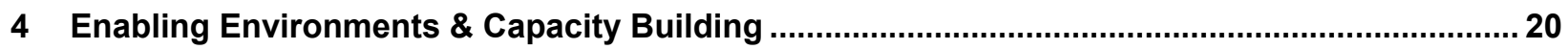

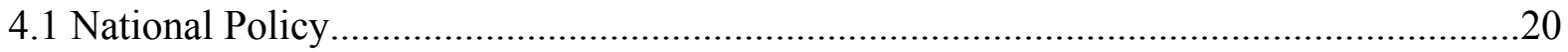

4.2 International Collaboration for National Sectoral Deployment and Diffusion Programs .23

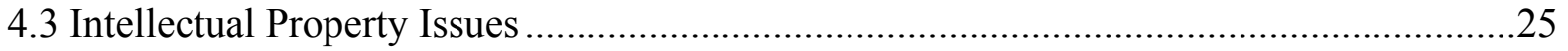

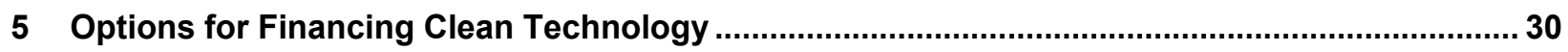

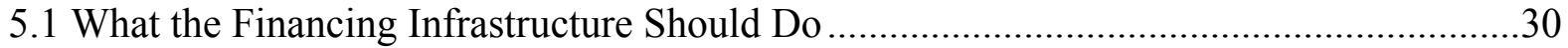

5.2 Components of a Financing Infrastructure ..............................................................30

5.3 Implementation and Institutional Arrangements for Facilitating Low Carbon Technology

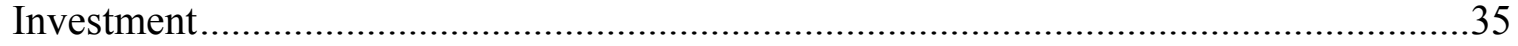

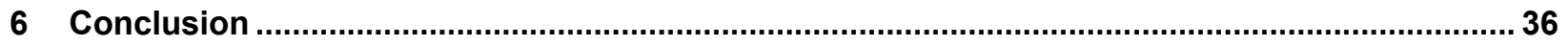

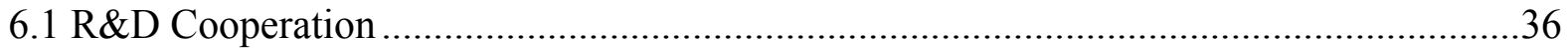

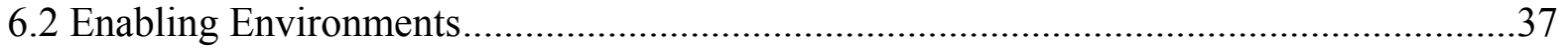

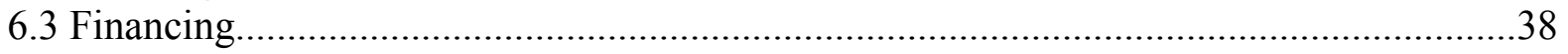

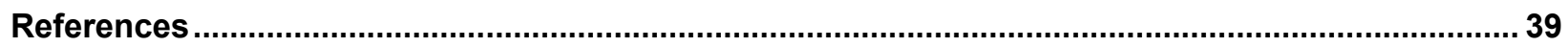




\section{List of Figures}

Figure 1. Possible integrated framework for clean energy R\&D cooperation........................................ 18

Figure 2. Example of implementation responsibilities for global clean energy R\&D cooperation ............ 19

Figure 3. Organizational structure for implementing TNA in a country .............................................. 21

\section{List of Tables}

Table 1. Selected International Clean Energy Technology Cooperation Options Evaluated in this Paper...

Table 2. Comparison of Primary Implementation Attributes of Selected Clean Energy Technology

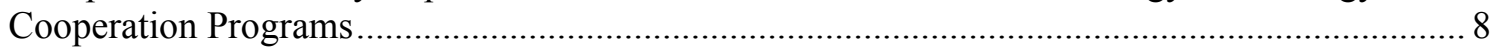

Table 3. Potential Structure of R\&D Networks \& Roadmaps ........................................................... 11

Table 4. Potential Structure for Multilateral R\&D Cooperation Projects ............................................... 14

Table 5. Potential Structure of Technology Demonstration Collaboration................................................ 16

Table 6. Possible Features of an Investment Matchmaking and Advisory Service ..................................31

Table 7. Possible Features of Existing Fund Coordination ................................................................. 33

Table 8. Possible Features of Investment Risk Mitigation Vehicles ....................................................... 34 


\section{Introduction}

Accelerating the transition to clean energy technologies can play a critical role in addressing international climate stabilization goals and creating a foundation for sustained economic growth. According to estimates made by the International Energy Agency, stabilizing greenhouse gas concentrations would require global clean energy investments totaling over $\$ 10$ trillion ${ }^{1}$ between 2010 and 2030, with most of this investment coming from the private sector. International clean energy cooperation can help to facilitate the transition to a low emissions energy future while simultaneously meeting rapidly growing energy demand in developing countries, where demand is projected to double by 2030 (OECD/IEA 2009).

Although an array of programs exists to foster international cooperation, these programs are not yet operating at the scale and scope, or in the coordinated manner necessary, for a rapid global clean energy transformation. This paper reviews current mechanisms and international frameworks for global cooperation on clean energy technologies, both within and outside of the United Nations Framework Convention on Climate Change (UNFCCC), and provides selected concrete options for scaling up global clean energy technology cooperation. The options are organized into three categories: 1) research and development (R\&D), 2) enabling environments, and 3) financing (see Table 1).

Table 1. Selected International Clean Energy Technology Cooperation Options Evaluated in this Paper

\begin{tabular}{|l|l|l|}
\hline \multicolumn{1}{|c|}{ Research and Development } & \multicolumn{1}{|c|}{ Enabling Environments } & \multicolumn{1}{c|}{ Financing } \\
\hline R\&D networks and road mapping & National policies & $\begin{array}{l}\text { Investment matchmaking and } \\
\text { advisory services }\end{array}$ \\
\hline Multilateral R\&D collaboration & $\begin{array}{l}\text { International cooperation on } \\
\text { sectoral deployment programs }\end{array}$ & Coordination of existing funds \\
\hline $\begin{array}{l}\text { Technology demonstration } \\
\text { partnerships }\end{array}$ & Intellectual property rights & Investment risk mitigation \\
\hline
\end{tabular}

Development of a comprehensive and effective global clean technology cooperation framework will require years of experimentation with and evaluation of new instruments and institutional arrangements before it is clear what works, on which scale, and in which region or country. In presenting concrete examples, this paper aims to take the first step in that process by highlighting successful models and innovative approaches that can inform efforts to ramp up clean energy technology cooperation. This is not an exhaustive treatment of options since only a couple of noteworthy examples are presented in each area.

The post-2012 climate change framework established at the COP-15 meeting in Copenhagen leaves unresolved the question of how countries will collaborate in advancing development and deployment of climate change mitigation and adaptation technologies. The agreement to launch a technology mechanism and the commitment to "fast-track" financing in the Copenhagen Accord are a first start, but there is much left to be specified. International organizations may be best served through the application of pragmatic approaches that build on proven models and

\footnotetext{
${ }^{1} 2008$ U.S. dollars.
} 
existing initiatives and partnerships and through tailoring activities to meet unique circumstances and needs. This paper presents examples and approaches that can inform the design of such flexible and practical technology initiatives.

Chapter 2 reviews and compares current climate change technology cooperation programs. Chapters 3-5 present examples and optional frameworks for R\&D, enabling environment, and financing cooperation. The final chapter presents conclusions on potential implementation frameworks for technology cooperation under the UNFCCC, drawing on the review of current programs and analysis of potential frameworks for R\&D, enabling environment, and financing cooperation. 


\section{Current Implementation Frameworks for Clean Energy Technology Cooperation under the UNFCCC}

A wide diversity of multilateral and bilateral programs encourages cooperation between developed and developing countries in the realm of clean energy technology development, deployment, and diffusion in support of the UNFCCC. This section reviews these programs, highlighting their implementation attributes.

\subsection{Current UNFCCC Technology Cooperation Framework}

The existing framework for technology cooperation under the UNFCCC (UNFCCC 2008b adopted by UNFCCC 2002) contains five elements: 1) technology needs assessments by developing countries; 2) technology information dissemination; 3) capacity building for developing countries; 4) enabling environment programs to improve conditions in countries for adoption and investment in climate technologies; and 5) mechanisms for technology transfer. With support through the Global Environment Facility (GEF), the United Nations Environment Program and United Nations Development Program are supporting the preparation of technology needs assessments while the UNFCCC Secretariat has established TT:CLEAR as a comprehensive clearinghouse for information on climate change technologies, needs assessments, and other related topics. Programs to address capacity building and improve enabling environments are implemented through a variety of multilateral and bilateral donors and organizations.

During the Bali Conference of the Parties (COP), a decision (UNFCCC 2008b) was adopted that calls for mechanisms and means for strengthening cooperation on technology R\&D, deployment, diffusion, and transfer. The UNFCCC has established an Expert Group on Technology Transfer (EGTT) with 19 members and additional resource representatives to facilitate technology transfer implementation under the UNFCCC. The EGTT recently released a strategy paper that presents long-term options for scaling up technology cooperation to implement this decision.

The EGTT strategy paper (EGTT 2009) presents a four-pronged approach for scaling up technology cooperation through: 1) research, development, and demonstration (RD\&D) cooperation; 2) enhanced enabling environments; 3) financing facilitation and support; and 4) sectoral planning and cooperation. The paper reviews a broad array of potential options that could be conducted in each of these four areas to achieve three objectives relating to climate change mitigation and adaptation technologies:

- Accelerate innovation across the world.

- Scale-up deployment, especially in developing countries.

- Speed-up diffusion, especially in developing countries.

The EGTT strategy paper also presents an array of functional and administrative implementation frameworks. The functional approaches include those centered on national plans and programs, sectoral initiatives (global, regional, and national), the four program elements, and specific crosscutting initiatives. These functional approaches can be combined with centralized, decentralized, and hybrid administrative options. A centralized approach is one in which all programs are conducted under one structure, whereas a decentralized approach would distribute 
implementation among many organizations and varying approaches, and a hybrid approach matches the structure to the type of implementation that will work best for the particular program.

\subsection{Summary of Selected International Clean Energy Technology Cooperation Programs}

A large number of organizations are implementing clean energy technology cooperation programs among countries to accelerate technology innovation and deployment and reduce global greenhouse gas emissions. This includes numerous bilateral programs along with such multilateral initiatives and agencies as the Asia Pacific Partnership on Clean Development and Climate, the Major Economies Forum, the Global Environment Facility and Multilateral Development Agencies, the Clean Development Mechanism, the Climate Technology Initiative, the International Energy Agency, the International Partnership for Energy Efficiency Cooperation, and the newly created International Renewable Energy Agency. This section of the paper briefly reviews the various frameworks for accelerated clean energy technology cooperation that each of these groups is putting forward. This is not an exhaustive treatment of this topic, as there are many other programs and organizations supporting international clean energy initiatives that will reduce global greenhouse gas emissions.

\subsubsection{Asia Pacific Partnership on Clean Development and Climate}

Through the Asia Pacific Partnership on Clean Development and Climate (APP; http://www.asiapacificpartnership.org/english/default.aspx), government, private sector, and technical institute representatives from Australia, Canada, China, India, Japan, South Korea, and the United States are working together to promote cooperation on clean energy and other climate mitigation technologies. The APP is supporting a portfolio of projects under eight sectoral task forces - aluminum, buildings and appliances, cement, cleaner fossil energy, coal mining, power generation and transmission, renewable energy and distributed generation, and steel. The APP projects cover a broad portfolio of activities with emphasis on technology demonstration and deployment through public-private partnerships.

\subsubsection{Major Economies Forum}

The Major Economies Forum (MEF), comprised of the 17 countries with the largest economies, has developed a portfolio of 10 Technology Action Plans (TAPs) to advance global cooperation on clean energy technologies. These plans cover advanced vehicles, bio-energy, buildings energy efficiency, carbon capture and storage, high efficiency and low emissions coal, industrial energy efficiency, marine energy, smart grids, solar energy, and wind energy. These action plans identify a portfolio of measures in three main areas: 1) advancing innovation; 2) facilitating information sharing; and 3) accelerating deployment. The MEF action plans identify both measures that individual countries can take and opportunities for collaborative action across countries.

\subsubsection{Global Environment Facility and Multilateral Development Agencies}

The Global Environment Facility (GEF) was established in 1991 and is a primary implementation mechanism for financial support on climate change, ozone, and biodiversity issues to developing countries. The GEF provides grants and technical assistance to developing countries for climate change programs, including clean energy projects. These GEF projects are designed to play a catalytic role in overcoming market barriers to the uptake of energy 
efficiency, renewable energy, sustainable transportation, and other low emitting technologies. Through 2010, the GEF has provided around $\$ 2.5$ billion in support of diffusion of climate mitigation and adaptation technologies in over 50 developing countries, with most of these resources supporting clean energy projects. A recent analysis by the Ecologic Institute (Gerstetter and Marcellino 2009) indicates that GEF support, while substantial, represents less than $2 \%$ of total multilateral and bilateral clean energy support to developing countries. GEF projects are implemented by the World Bank and other multilateral development banks and by United Nations agencies. These development banks and UN organizations also have their own portfolios of clean energy technology cooperation programs, which are too numerous to describe here.

\subsubsection{Clean Development Mechanism}

The Clean Development Mechanism (CDM) allows countries with Kyoto Protocol GHG targets to achieve emission reductions through projects in developing countries. Total investments associated with the CDM are estimated at some US\$10 billion annually (UNFCCC 2008c). Nearly $60 \%$ of the over 1,200 registered CDM projects as of the end of 2008 were in the energy sector (UNFCCC 2008a). An analysis by Stephen Seres and Eric Haites (2008) indicates that over a third of the registered and proposed CDM projects claim technology transfer benefits, including both knowledge and equipment transfer from sponsor to host countries.

\subsubsection{The Climate Technology Initiative}

The Climate Technology Initiative (CTI; www.climatetech.net) is a multilateral partnership that supports international cooperation to advance adoption and diffusion of climate friendly technologies. CTI was established in 1995 and has supported an array of programs to advance use of clean energy and other climate mitigation and adaptation technologies. Current initiatives include the Private Financing Advisory Network (PFAN) to assist clean energy companies in developing countries in attracting financing through matchmaking and advisory services, symposium and training programs on climate technologies, technical assistance for technology needs assessments, and various information dissemination activities.

\subsubsection{International Energy Agency}

The International Energy Agency (IEA) includes 24 member countries from the developed world working together to advance energy security, economic growth, and environmental protection. The IEA international clean energy technology collaboration activities involve three primary activities: 1) developing global energy technology roadmaps and analysis on a technologyspecific basis that provide consensus on technology development, legal/regulatory, financial, and public engagement/outreach needs; 2) expanding technology analysis work with key nonmember countries (including Brazil, China, India, Indonesia, Russia, and South Africa) to expand cost-benefit modeling, scenario assessment, and technology roadmaps at the national level; and 3) managing an existing network of 42 international energy technology cooperation implementing agreements that involve shared RD\&D and analysis activities. These networks have recently been expanded to reach out to non-member countries via the NEET (Networks of Expertise on Energy Technologies) initiative.

\subsubsection{International Partnership for Energy Efficiency Cooperation}

The G8 countries plus Brazil, China, India, Korea, Mexico, and the European Commission are working together to accelerate the implementation of energy efficiency through the recently 
established International Partnership for Energy Efficiency Cooperation (IPEEC; http://ipeecshare.org). IPEEC has developed an initial portfolio of cooperative projects to share best practices, build capacity, and provide expert assistance in five areas: 1) energy efficiency financing; 2) energy efficiency measurement and verification; 3) industrial efficiency energy management; 4) energy efficiency policies through the World-wide Energy Efficiency Action through Capacity Building and Training (WEACT) initiative; and 5) the Sustainable Buildings Network. IPEEC encourages other countries and international institutions to join the partnership and its specific programs. The IPEEC Secretariat, located at the IEA, coordinates initiatives across countries and maintains an inventory of national and international energy efficiency policies and programs.

\subsubsection{International Renewable Energy Agency}

As of October 2009, 138 countries are members of the new International Renewable Energy Agency (IRENA; www.irena.org). IRENA's mandate is to accelerate the global transition to widespread and sustainable renewable energy use. IRENA seeks to improve access, especially for developing countries, to renewable energy information and data, policy and program best practices, financing mechanisms, and technology expertise. IRENA has developed a collaborative work program that includes renewable energy knowledge management and technology assessment and capacity building and outreach, especially for developing countries. This work program is being launched in 2010 .

\subsubsection{Bilateral Programs}

Many developed countries provide in-depth assistance to developing countries on a bilateral basis to overcome technical, market, and capacity barriers to increased clean energy use. Taken together, these bilateral programs are often the largest source of clean energy assistance and can involve extensive technology cooperation linking technical institutes and the private sector between the countries. There are also an increasing number of cases where developed and larger developing countries are working together on clean energy research, development, and demonstration cooperation. These bilateral programs are too numerous to describe here.

In addition to the above examples, there are many other multilateral and bilateral programs and forums that are advancing global clean energy cooperation that are not discussed here.

\subsection{Comparison of Implementation Attributes of Existing Programs}

The various proposals that have been put forward for accelerating implementation of technology transfer under the UNFCCC highlight several desired attributes (see example in Gerstetter and Marcellino 2009). In addition, experiences from current and past technology transfer programs also highlight key lessons on effective program structures and delivery (see for example Kline et al. 2003). In reviewing the current proposals and experiences from current and past technology transfer programs, the following desired implementation attributes can be identified:

- Focus on Well Defined and Broadly Endorsed National Priorities. Technology cooperation will be most effective where it addresses national priorities defined in existing development plans that have been subjected to a rigorous evaluation and that enjoy strong support from public and private stakeholders. 
- Strengthen Developing Country Capacity and Enabling Environments. International technology cooperation efforts will only result in sustained impacts if they build capacity and effective enabling environments in the host country.

- Apply a Comprehensive Approach and Sufficient Scale Over Multiple Years. Initiatives to advance technology cooperation should address all aspects of the technology life cycle in a country, including technology adaptation and commercialization (and innovation where applicable), demonstration, deployment, and financing. Implementation should be conducted at sufficient scale of resources and over multiple years to achieve substantial and lasting global impacts.

- Build Long-Term Public and Private Partnerships. Collaboration has the greatest value where it establishes long-term partnerships among developing and developed country technical institutes, companies, governments, and civil society. It is essential to actively engage the private sector to help accelerate private investment and business partnerships between countries.

- Engage all Regions and Promote Knowledge Sharing across Countries. Technology cooperation efforts should engage countries from all regions of the world and all levels of development and take full advantage of opportunities for countries to learn from each other through knowledge sharing at regional and global levels.

- Coordinate International Programs. The large array of bilateral and multilateral technology cooperation programs can achieve maximum impact if they are effectively coordinated so that resources can be leveraged and activities harmonized.

Table 2 identifies which of these features are emphasized by some of the largest clean energy technology cooperation programs currently conducted in support of UNFCCC goals. While recognizing that all programs may give some level of attention to most of these issues, programs are only marked if they have made a feature a defining characteristic of their activities. It is important to note that the comparison of these key attributes only provides qualitative information on how often such features are addressed and is not a determination of program effectiveness since many other factors can drive program impacts. 
Table 2. Comparison of Primary Implementation Attributes of Selected Clean Energy Technology Cooperation Programs

\begin{tabular}{|c|c|c|c|c|c|c|c|c|c|c|c|}
\hline $\begin{array}{l}\varepsilon \\
\frac{\varepsilon}{0} \\
\frac{0}{0} \\
\frac{0}{0}\end{array}$ & 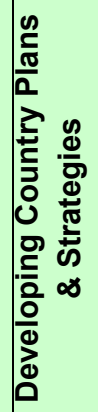 & 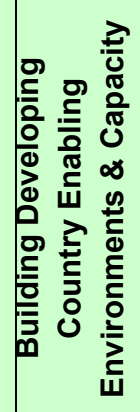 & 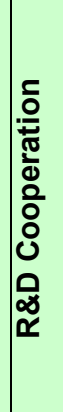 & 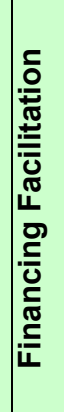 & 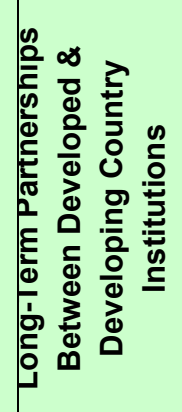 & 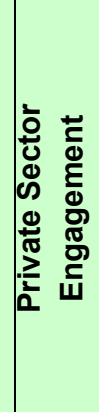 & 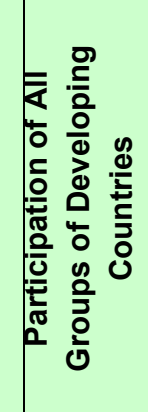 & 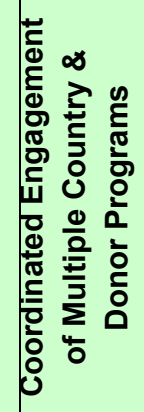 & 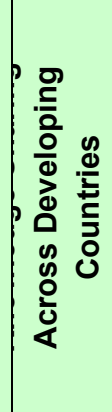 & 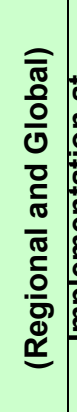 & 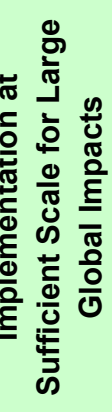 \\
\hline TT:CLEAR & $\bullet$ & & & & & & $\bullet$ & & $\bullet$ & & \\
\hline GEF & $\bullet$ & $\bullet$ & $\bullet$ & $\bullet$ & $\bullet$ & $\bullet$ & $\bullet$ & & & & $\bullet$ \\
\hline CDM & & & & $\bullet$ & $\bullet$ & $\bullet$ & $\bullet$ & & & & $\bullet$ \\
\hline APP \& MEF & & $\bullet$ & $\bullet$ & $\bullet$ & $\bullet$ & & & $\bullet$ & & & \\
\hline $\begin{array}{l}\text { MDB \& UN } \\
\text { Programs }\end{array}$ & - & $\bullet$ & & $\bullet$ & & $\bullet$ & - & & $\bullet$ & & $\bullet$ \\
\hline $\begin{array}{l}\text { Bilateral } \\
\text { Programs }\end{array}$ & 促 & 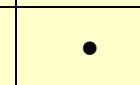 & 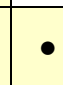 & - & 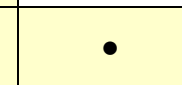 & 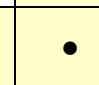 & & & & & - \\
\hline IEA & $\bullet$ & & $\bullet$ & & & & & $\bullet$ & & & \\
\hline $\begin{array}{l}\text { Technology } \\
\text { Agencies \& } \\
\text { Partnerships } \\
\text { (e.g., } \\
\text { IRENA, } \\
\text { IPEEC, etc.) }\end{array}$ & & - & & $\bullet$ & & & & $\theta$ & & & \\
\hline CTI & $\bullet$ & $\bullet$ & & $\bullet$ & & $\bullet$ & & $\bullet$ & & & \\
\hline
\end{tabular}

A number of conclusions can be drawn from this comparison:

- The programs emphasize many different aspects of technology cooperation, allowing for specialization.

- There is considerable overlap in goals and activities across these programs and a potential need for initiatives to foster enhanced coordination and harmonization of related activities. This can include efforts to coordinate development of tools and delivery of training and technical assistance to improve efficiency of resource use and quality of support provided to developing countries.

- Few programs have made significant investments in broad and effective knowledge sharing among developing countries at regional and global levels. 
- Only a couple of programs adopt a comprehensive approach that covers R\&D, enabling environment (or deployment), and financing facilitation to address the full suite of barriers to technology diffusion.

- Only some of the programs entail strong partnerships with the private sector.

- Many programs focus primarily on a subset of developing countries and do not have impacts across regions and sizes of developing countries.

- Only some of the programs are designed to be maintained over a long time period to allow for sustained, long-term partnerships.

- Just a couple of the programs currently operate at the large scale required for significant global impacts in accelerating technology diffusion. 


\section{Clean Energy R\&D Cooperation}

\subsection{Role of Global R\&D Cooperation}

Various studies (see for example the IEA Energy Technology Perspectives 2008 Blue Map Scenario and a more recent R\&D gap analysis conducted for the MEF) have estimated that up to $\$ 70$ billion per year is required in additional public and private investment in clean energy R\&D to advance innovation and achieve climate stabilization (IEA 2008). This compares to current public clean energy R\&D expenditures of around $\$ 5$ billion per year. Such enhanced R\&D investment will have the greatest impact if conducted in a coordinated manner that harmonizes activities toward common strategic goals. This paper elaborates on three options for global R\&D cooperation:

- $R \& D$ Networks and Roadmaps. Where R\&D activities are conducted in a coordinated fashion by sector and by technology at global, regional, and national levels and guided by shared technology roadmaps.

- Multilateral R\&D Cooperation. Countries, along with the private sector and international institutions, can conduct multilateral R\&D collaboration through coordinated projects and in some cases through joint R\&D solicitations.

- Technology Demonstration Partnerships. Public and private agencies can also coordinate support for demonstration of emerging technologies, including expanding such demonstrations in developing countries.

There are other key approaches for facilitating R\&D cooperation that deserve consideration, including establishment of regional centers of innovation, research exchange and training programs, joint work on technology standards and certification, and portals to share R\&D data. In this paper, these activities are presented as initiatives that would be pursued by the R\&D technology networks, but they can also be conducted on an independent basis.

\subsection{Example Structure for R\&D Networks and Road Mapping}

A global transformation to low carbon energy technologies requires that all countries work in concert in addressing common R\&D challenges. One approach for building global R\&D capacity and for coordinated application of knowledge is to establish an interlinked set of global, regional, and national R\&D networks. Such networks could bring together leading technical institutions, funding agencies, the private sector, and international organizations to accelerate progress toward shared $\mathrm{R} \& \mathrm{D}$ goals while building R\&D capacity and knowledge throughout the world. These networks can be organized by technology, guided by shared roadmaps, and reached by a broad audience through use of virtual communication.

Activities conducted by clean energy R\&D networks could include:

- Strengthening regional and national centers of innovation in developing countries and linking these centers with similar institutions in developed countries.

- Developing global and regional technology roadmaps articulating a shared technology vision and plan for coordinated R\&D programs to achieve this vision.

- Sharing information and providing training on R\&D methods and simulation tools. 
- Creating common databases on technology performance and research results.

- Fostering collaboration on performance standards, certification, and testing.

- Facilitating researcher exchanges between countries and development of enhanced science and engineering educational programs.

- Coordinating joint research and demonstration projects (elaborated further later in this section).

Table 3 provides an example design for such R\&D networks and roadmaps.

Table 3. Potential Structure of R\&D Networks \& Roadmaps

\begin{tabular}{|c|c|}
\hline Goals & $\begin{array}{l}\text { - To build technical capacity to support clean energy technology innovation, } \\
\text { adaptation, commercialization, and deployment in all countries and regions. } \\
\text { - To develop shared visions for R\&D pathways and coordinate application of } \\
\text { knowledge and expertise across countries to address common goals. }\end{array}$ \\
\hline Participants & $\begin{array}{l}\text { - Research funding agencies from countries with programs for the selected } \\
\text { technology. } \\
\text { - } \quad \text { Research institutions (e.g., labs and universities) playing leading roles for that } \\
\text { technology, including regional centers of excellence. } \\
\text { - International technology organizations and networks. } \\
\text { - Private sector and foundation research sponsors. }\end{array}$ \\
\hline $\begin{array}{l}\text { Scope of } \\
\text { Activities }\end{array}$ & 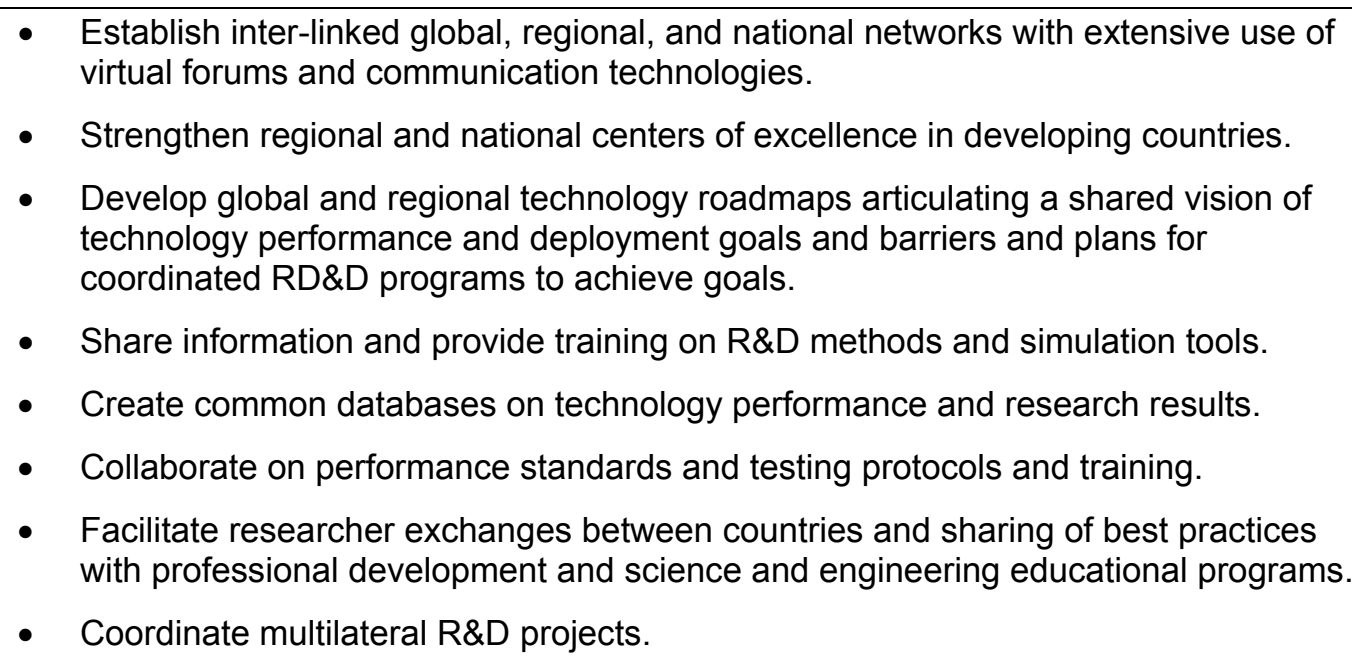 \\
\hline $\begin{array}{l}\text { Selected } \\
\text { Current } \\
\text { Examples }\end{array}$ & $\begin{array}{l}\text { - } \text { Consultative Group for International Agricultural Research (http://www.cgiar.org). } \\
\text { - Sustainable Buildings Network as launched by Heiligendamm Process and the G8. } \\
\text { - } \quad \text { IEA technology roadmaps and implementing agreements } \\
\text { (http://www.iea.org/textbase/techno/index.asp ). }\end{array}$ \\
\hline $\begin{array}{l}\text { Resource } \\
\text { Levels }\end{array}$ & $\begin{array}{l}\text { - } \$ 1-2 \text { million/year may be the minimum required by technology to establish linked } \\
\text { virtual global networks and regional centers of excellence and conduct the above } \\
\text { activities. }\end{array}$ \\
\hline
\end{tabular}




\begin{tabular}{|c|c|}
\hline Benefits & $\begin{array}{l}\text { - Strengthened technical capacity will accelerate technology innovation and } \\
\text { deployment around the world. } \\
\text { - Coordinated R\&D harness global knowledge and resources to advance progress } \\
\text { toward shared technology research and deployment goals. }\end{array}$ \\
\hline $\begin{array}{l}\text { Constraints \& } \\
\text { Strategies }\end{array}$ & $\begin{array}{l}\text { - Global reach-use of virtual forums and communication technologies. } \\
\text { - Participation of least developed countries (LDCs)_establish regional centers of } \\
\text { excellence and encourage countries to identify national focal points to help build } \\
\text { in-country capacity. } \\
\text { - Implement global roadmaps at the national/sectoral levels; specific strategies are } \\
\text { needed to ensure implementation. }\end{array}$ \\
\hline
\end{tabular}

Various approaches can be pursued in strengthening and launching such R\&D networks and joint roadmapping activities. These networks can be guided by an advisory group of technology R\&D experts from developed and developing countries. Networks can be managed by existing international clean energy partnerships and agencies, such as the energy partnerships established by the MEF, the IEA, the IRENA, and the IPEEC. The GEF, MDBs, and UN agencies could partner with these groups in implementing programs focused specifically on developing countries (e.g., strengthening national and regional centers of excellence). Network participants should include technical institutes and government and business representatives from around the world. A possible implementation approach could include the following steps:

1. Establish Advisory Group to Review Existing Technology Networks and Gaps. A review could be conducted of existing and planned technology networks to identify gaps in current activities, needs for additional networks that address clean energy technologies of broad global relevance (e.g., sustainable buildings, solar technologies, efficient appliances, biomass technologies, industrial efficiency, and efficient vehicles), and includes participants from all regions. This review could also identify appropriate bodies to manage networks for specific sectors looking to complement the work of existing international organizations and groups. This could include a thoughtful assessment of the strengths and weaknesses of existing organizations and networks and strategies to overcome these limitations.

2. Identify Sectoral Agencies or Partnerships Responsible for Managing Networks. The advisory group could offer recommendations or options for assigning responsibility for management of networks to existing international energy agencies and partnerships.

3. Develop Global and Regional Plans for Strengthening Networks. The advisory group could develop an action plan for enhancing the work of existing technology networks and creating new networks where needed. This plan would define performance metrics and identify funding sources and steps for securing needed funding. It would also include a review and accountability process for networks to report on progress and adjust their activities over time.

4. Expand Current Networks and Launch New Networks. This could include expanding the scope of participants and coverage of existing networks and creating new networks where required. Emphasis should be given to virtual networks to reduce the carbon impacts and costs of travel. 
5. Strengthen National Regional Centers of Excellence. To enable effective participation by developing countries, efforts could be undertaken to strengthen the capacity of regional and national centers of excellence and innovation. It is important to realize that networks should have meat on their bones - a network alone is not enough. R\&D institutions in developed countries often have sufficient capabilities to be part of an international network. Networks and other international R\&D cooperation initiatives will be most effective where they provide assistance for such science and technology capacity building programs in developing countries.

6. Develop Global and Regional Roadmaps. The networks could prepare roadmaps that define common technology development, demonstration, and deployment goals and coordinate activities at global and regional levels to achieve those goals.

7. Implement Joint Projects. Consistent with the roadmaps, the networks could coordinate implementation of collaborative projects on specific R\&D or analysis topics of common interest. Such projects could focus on pre-competitive topics that do not involve sensitive intellectual property. Joint work on technology standards, certification, and training could also be conducted.

8. Facilitate Researcher Exchange and Education. The networks could coordinate exchange of researchers and other technology experts, virtual and in-person training programs, and efforts to help strengthen scientific and technical education programs in developing countries.

9. Establish Portals to Exchange Information. The networks could create community web portals and forums to disseminate information on R\&D, analysis, and deployment activities and results, methods and tools, training materials, and other resources.

\subsection{Example Implementation Structure for Multilateral R\&D Cooperation}

$R \& D$ cooperation across countries can serve as a force multiplier, accelerating progress toward shared clean energy research and development goals. In addition to the R\&D capacity building (e.g., strengthening centers of innovation and training) and information sharing activities described earlier as potential elements of technology networks, countries can also work together in implementing focused $R \& D$ projects. These $R \& D$ projects can be conducted on a bottom-up basis where institutions identify alignment of interests and pursue joint projects or in more of a top-down manner through joint solicitations and collaborative R\&D programs managed and driven by government's partnerships. While this paper presents examples for multilateral collaborative $R \& D$ projects, these same approaches can be applied bilaterally where there is a growing portfolio of R\&D partnerships. Technology networks or alliances can coordinate implementation of collaborative R\&D projects, ideally guided by shared roadmaps. 
Table 4. Potential Structure for Multilateral R\&D Cooperation Projects

\begin{tabular}{|c|c|}
\hline Goals & $\begin{array}{l}\text { - To harness funding across countries in advancing common R\&D priorities. } \\
\text { - To foster research institution and private sector partnerships between countries. } \\
\text { - To enable broad dissemination of R\&D methods and results. }\end{array}$ \\
\hline Participants & $\begin{array}{l}\text { - All countries invited to participate in solicitations and multilateral projects. } \\
\text { - } \quad \text { Private sector, international institution, and foundation engagement and funding. } \\
\text { - } \quad \text { Research institutions from across the world. }\end{array}$ \\
\hline $\begin{array}{l}\text { Scope of } \\
\text { Activities }\end{array}$ & $\begin{array}{l}\text { - Identify common interests and establish collaborative teams. } \\
\text { - Determine the best form of collaboration (e.g., bottom-up multiparty projects or } \\
\text { joint solicitations). } \\
\text { - Establish collaborative R\&D agreements for bottom-up multiparty projects. } \\
\text { - Pool resources across countries and issue a solicitation for the R\&D topics of } \\
\text { common interest for joint solicitations. } \\
\text { - Form multi-country teams and submit proposals. } \\
\text { - Disseminate methods and results through Web sites, workshops, and other } \\
\text { forums. }\end{array}$ \\
\hline $\begin{array}{l}\text { Selected } \\
\text { Current } \\
\text { Examples }\end{array}$ & $\begin{array}{l}\text { - European Commission and the Government of India joint solar research solicitation } \\
\text { (http://cordis.europa.eu/fp7/dc/index.cfm?fuseaction=UserSite.CooperationDetails } \\
\text { CallPage\&call_id=257). } \\
\text { - U.S.-Israel solicitations on renewable energy and energy efficiency R\&D } \\
\text { (http://www.birdf.com//ndex.asp?CategoryID=118\&ArticleID=321 and } \\
\text { http://www.bsf.org.il/BSFPublic/Default.aspx). } \\
\text { - European Energy Research Alliance (http://www.eera-set.eu) with sub-networks } \\
\text { organized by topic. }\end{array}$ \\
\hline $\begin{array}{l}\text { Resource } \\
\text { Levels }\end{array}$ & $\begin{array}{l}\text { - Joint solicitations on specific topics could be issued for as little as US\$1 million. } \\
\text { - } \quad \text { Multilateral projects may be cost neutral when integrating existing R\&D activities. }\end{array}$ \\
\hline Benefits & $\begin{array}{l}\text { - } \text { Tapped resources across countries to achieve common R\&D goals. } \\
\text { - Accelerated innovation and learning across the world. }\end{array}$ \\
\hline $\begin{array}{l}\text { Constraints \& } \\
\text { Strategies }\end{array}$ & $\begin{array}{l}\text { Developing country participation-could have lower minimum funding levels or } \\
\text { explore sponsorship from international organizations for low income countries. } \\
\text { - IP management-can focus on non-competitive topics and, where needed, require } \\
\text { that team members establish agreements for IP ownership and protection. } \\
\text { - Transaction costs-establish efficient mechanisms for administering program, such } \\
\text { as use of non-government foundations or other similar organizations. }\end{array}$ \\
\hline
\end{tabular}


Implementation of multilateral $R \& D$ projects can be driven by the networks and associated roadmaps and managed by existing international energy agencies and partnerships as described in the previous section. These networks could pursue the following steps:

1. Identify Research Topics of Common Interest. This identification of topics should flow from the technology roadmaps prepared by the networks.

2. Establish Teams for Each Topic to Plan Collaborative Work. These teams could include representatives from research institutions and government research agencies from developing and developed countries as well as international organizations (and the private sector where desired) interested in R\&D in the specific topic. This should also include a process for consulting with the private sector to identify opportunities to partner on $\mathrm{R} \& \mathrm{D}$ projects.

3. Determine the Most Effective Mode of Cooperation for each Topic. Voluntary multiparty projects, joint solicitations, or research outreach and exchange, for example.

4. Develop R\&D Plans, Metrics, and Review Processes. For each topic, a multiyear R\&D plan would be established with clear performance metrics and review procedures.

5. Secure Support. The teams would work with the interested governments, international organizations, and appropriate UNFCCC bodies to secure support for R\&D projects. This should include exploring opportunities for private sector co-funding.

6. Coordinate Implementation. The teams would be responsible for guiding implementation of the R\&D project.

7. Conduct Annual Review and Refine Plans. The teams could conduct annual peer reviews of results of $\mathrm{R} \& \mathrm{D}$ and reveal plans for the next year to reflect outcomes and lessons.

\subsection{Example Structure for Technology Demonstration Collaboration}

Similar to joint R\&D solicitations, countries, international institutions, and the private sector can also team in supporting demonstrations of emerging technologies to advance technology learning, reduce costs, and build global market acceptance. This can occur through two complementary mechanisms: 1) emerging technology demonstration partnerships to coordinate demonstrations across sponsoring countries and share results, tools, and lessons across all countries, and 2) expanding support for demonstrations in developing countries to foster technology adaptation, acceptance, and capacity building. Collaboration on demonstration of emerging technologies can harness collective resources in accelerating development and cost reductions of technologies that are not fully commercial and should engage both developed and developing countries. In addition, expanded support for demonstration of more technologies in developing countries will help build market awareness and acceptance and technical capacity and can inform adaptation of technologies to developing country markets. 
Table 5. Potential Structure of Technology Demonstration Collaboration

\begin{tabular}{|c|c|}
\hline Goals & $\begin{array}{l}\text { - To coordinate use of resources and knowledge across countries in reducing costs } \\
\text { and improving performance of emerging technologies around the world. } \\
\text { - To build broad awareness and acceptance of emerging technologies and technical } \\
\text { capacity to adapt technologies for use in developing countries. }\end{array}$ \\
\hline Participants & $\begin{array}{l}\text { - } \text { Developed and developing country technology demonstration funding agencies. } \\
\text { - Research institutions from all countries. } \\
\text { - International organizations and foundations. } \\
\text { - Private sector companies participating in implementation of demonstrations. }\end{array}$ \\
\hline $\begin{array}{l}\text { Scope of } \\
\text { Activities }\end{array}$ & 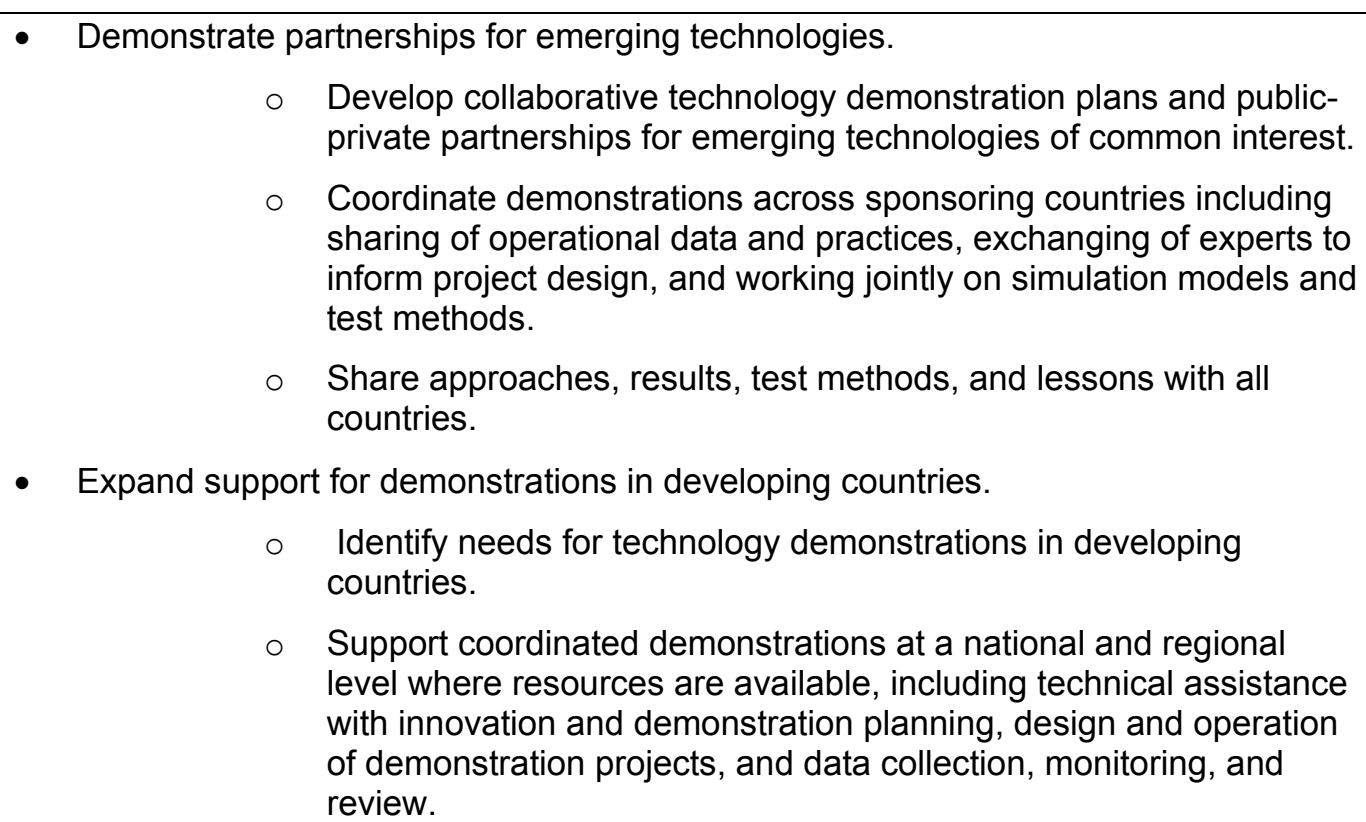 \\
\hline $\begin{array}{l}\text { Selected } \\
\text { Current } \\
\text { Examples }\end{array}$ & $\begin{array}{l}\text { - Over } 30 \text { countries are collaborating on demonstration and deployment of } \\
\text { technologies for reducing global emissions of methane through the Methane to } \\
\text { Markets Partnership (http://www.methanetomarkets.org). } \\
\text { - Countries are teaming on demonstration of carbon capture and sequestration } \\
\text { technologies through the Global Carbon Capture and Storage Institute } \\
\text { (http://www.globalccsinstitute.com). }\end{array}$ \\
\hline $\begin{array}{l}\text { Resource } \\
\text { Levels }\end{array}$ & $\begin{array}{l}\text { - Networks across countries already sponsoring emerging technology } \\
\text { demonstrations and sharing results, tools, and lessons may require as little as } \\
\text { US } \$ 200,000 \text { per technology, while new demonstration programs in developing } \\
\text { countries require much higher levels of resources. }\end{array}$ \\
\hline Benefits & $\begin{array}{l}\text { - Harmonized use of existing resources to efficiently overcome performance and } \\
\text { market acceptance challenges for emerging technologies. } \\
\text { - Supported adaptation of emerging technologies for developing country markets and } \\
\text { building technical capacity to speed market adoption. }\end{array}$ \\
\hline
\end{tabular}




\begin{tabular}{|l|ll|}
\hline $\begin{array}{l}\text { Constraints \& } \\
\text { Strategies }\end{array}$ & $\begin{array}{l}\text { Timing broad developing country demonstrations to ensure technology and market } \\
\text { readiness-employ rigorous technology and market reviews to inform } \\
\text { demonstrations. }\end{array}$ \\
- \begin{tabular}{l} 
Developing country participation—could sponsor participation in partnerships. \\
\hline
\end{tabular}
\end{tabular}

Demonstration partnerships (engaging both developed and developing countries) for emerging technologies can be conducted in parallel with expanded demonstration of technologies in developing countries designed to support technology adaptation and market acceptance. These two activities would reinforce each other, including sharing lessons and results from demonstrations and engaging similar experts in design of demonstration programs. Potential steps are similar to those for multilateral R\&D projects so are not repeated here.

The technology networks described earlier could take on lead responsibility for design and implementation of demonstration projects for the specific technologies consistent with the roadmaps they develop. The technology networks could have accountability to international energy agencies (e.g., IEA and IRENA) or partnerships (e.g., IPEEC and MEF) identified as the managing bodies for R\&D cooperation at the sectoral level. These managing organizations should work in partnership with the GEF, MDBs, and UN agencies in implementing demonstration projects with developing countries. It may be appropriate for the GEF to play a leading role in supporting expanding demonstration of technologies in developing countries consistent with their mission.

\subsection{Potential Integrated R\&D Clean Energy Cooperation Framework}

The three core elements described here (technology networks and roadmaps, multilateral R\&D cooperation, and technology demonstration partnerships) will be most effective when implemented in an integrated fashion. As shown in Figure 1, technology networks and roadmaps can serve as the primary integrating mechanism that guide and coordinate multilateral R\&D and technology demonstration cooperation. These networks can also serve as the organizing mechanism for R\&D capacity building, innovation center support, information sharing, technology standards, testing, and certification. Organization of R\&D networks by technology will allow them to gain traction and build from the existing technology driven structure of national R\&D programs and international R\&D collaboration. However, some consideration should also be given to system level networks (e.g., sustainable energy communities and vehiclegrid integration). The potential structure and steps for establishing such networks, engaging them in development of technology roadmaps, and instilling collaborative implementation of R\&D cooperation and emerging technology demonstration programs is presented in further detail in this section. 


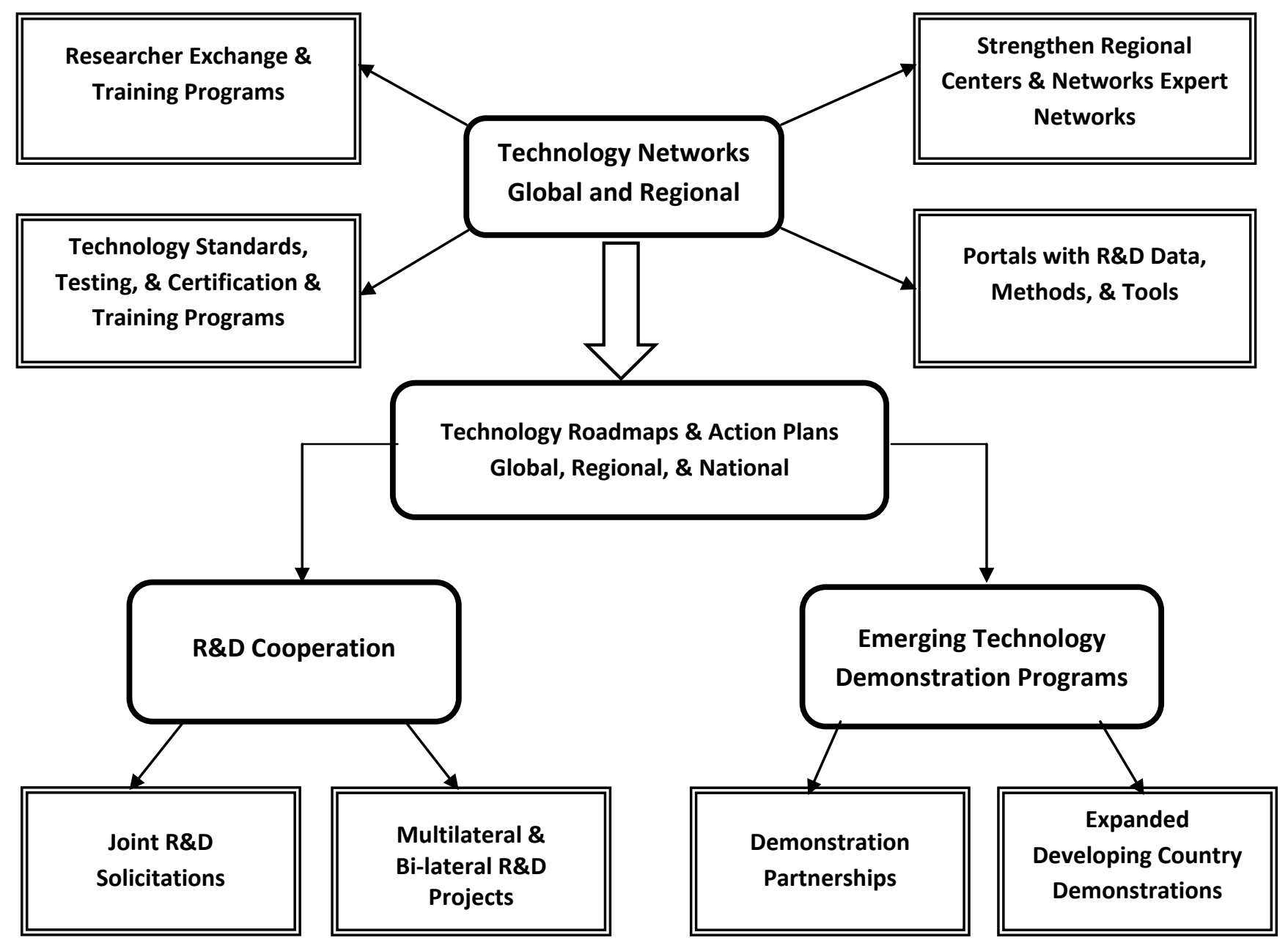

Figure 1. Possible integrated framework for clean energy R\&D cooperation.

As described in this section, the individual technology networks could have primary responsibility for conducting R\&D programs with accountability to existing international energy agencies or partnerships (e.g., IEA, IPEEC, IRENA ${ }^{2}$, and MEF energy technology partnerships) that provide overall management oversight and coordinate provision of resources for the work of the networks. The GEF, MDBs, and UN agencies could also manage delivery of programs focused specifically on developing countries (e.g., expanded demonstrations in those countries) and work in partnership with these international energy agencies and partnerships. In turn, the management agencies could report to an overall UNFCCC clean energy technology advisory group. These activities could be closely coordinated with bilateral programs. This is depicted in Figure 2.

\footnotetext{
${ }^{2}$ The emphasis of IRENA is more on building developing country capacity on renewable energy policies and deployment than on R\&D, so the IRENA role may be limited in this area.
} 


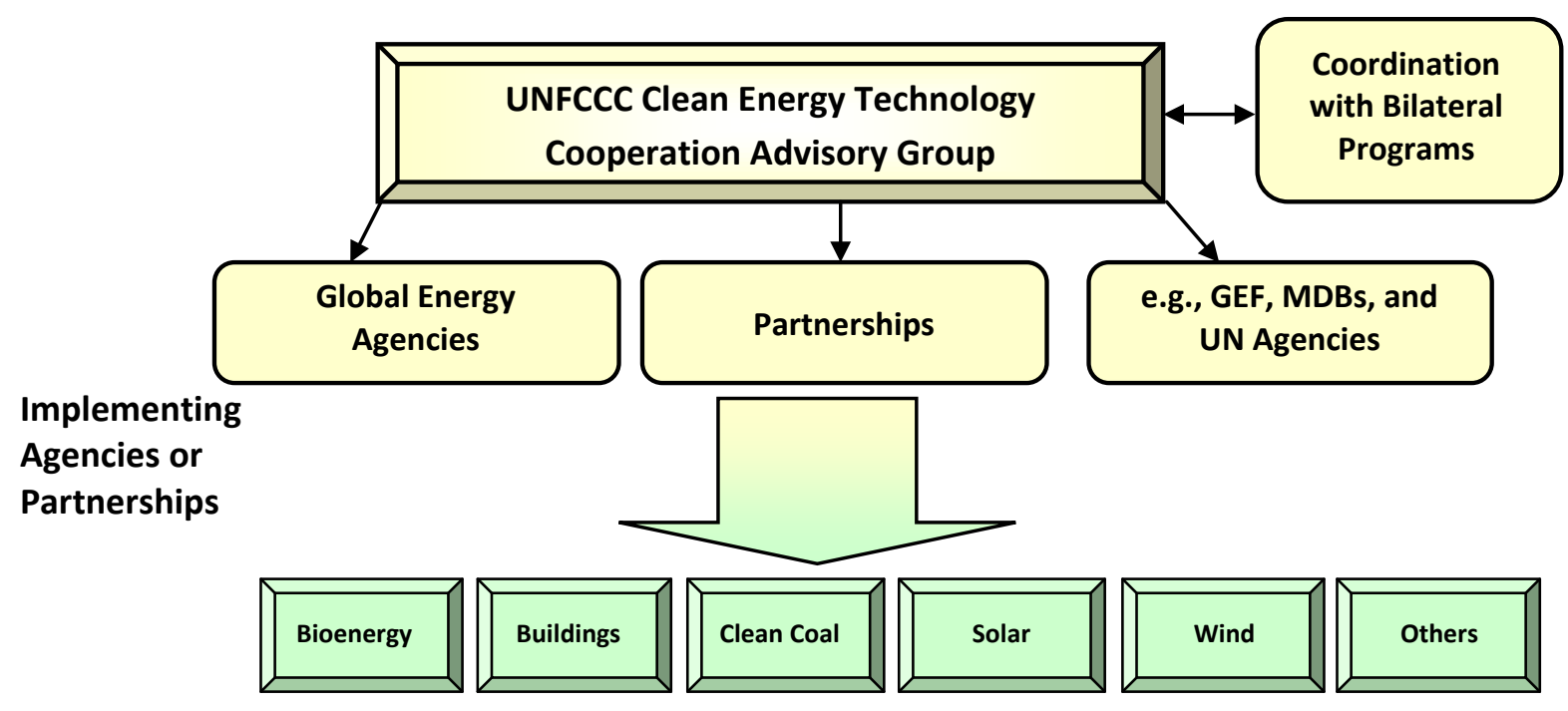

Technology

Networks

Figure 2. Example of implementation responsibilities for global clean energy R\&D cooperation 


\section{Enabling Environments \& Capacity Building}

This chapter reviews and illustrates how national policies and international collaboration for national sectoral deployment programs can create enabling environments for technology transfer and highlights the main issues concerning intellectual property. Each section is concluded with a discussion about an approach for the future.

\subsection{National Policy}

4.1.1 Role of National Policies and the Technology Needs Assessment Process National policies are defined as policies both formulated at the country level and policies formulated at the sub-country level, such as state, province, and municipality.

The lack of supportive local policy is a barrier to technology transfer and diffusion (Hoekman et al. 2005), and within the climate community, it is assumed that by providing financial and technical assistance to developing countries, national policies can be strengthened (EGTT 2009). Financial and technical assistance can be used to develop technology needs assessments (TNAs), technology standards, procurement programs and elements of nationally appropriate mitigation actions (NAMAs), and national adaptation programs of actions (EGTT 2009).

NAMAs have resulted in a lot of debate with respect to their definition (Olsen et al. 2009), and as a result, coming out of Copenhagen, there remains a trust deficit between developed and developing countries (Zevallos 2009). Therefore, mechanisms for helping developing countries prepare strategies for elaboration of NAMAs should help in building trust and improving the overall outcome.

TNAs are an element of enabling activities leading to NAMAs. UNEP is planning to implement GEF-supported TNA. The TNA approach involves wide stakeholder consultations within the countries through which priority technologies are identified (UNDP 2009). The technologies selected are based on a sustainability framework and would have to contribute to the economic, social, and developmental priorities. A wide stakeholder process (Figure 3) and explicit recognition of the developmental needs is expected to create a trust within developing countries in the TNA exercise.

The TNA exercise would go beyond technology prioritization to include identification of barriers to the acquisition, deployment, and diffusion of technologies and develop enabling frameworks to overcome the barriers in the form of an Action Plan. The Action Plan would provide a description of the measures that would be needed to 1) reduce risks and create a stable market, 2) provide incentives for cleaner technologies, 3) remove barriers created by existing policies, and 4) gain access to international funds and technologies. 


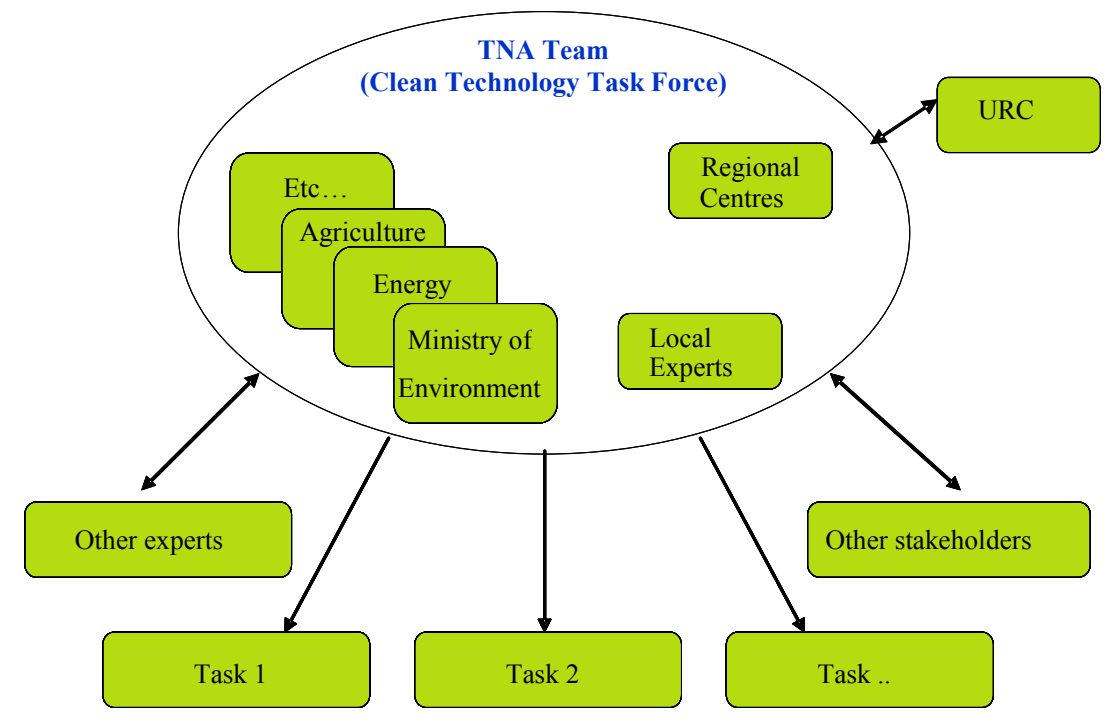

Figure 3. Organizational structure for implementing TNA in a country

Reducing risks to create stable markets, providing incentives for cleaner technologies, and removing policy distortions are all requirements for an enabling environment that depend on national policies. Some examples from developing countries show how national policies have been able to successfully support deployment and diffusion of technologies. Next, we examine one such case.

\subsubsection{Wind Energy}

Wind energy deployment in China and India has occurred at a fast rate during the last few years (REN21 2009) and contributed significantly to the reduction of GHG emissions in the country, since the electricity sector in both these countries is heavily dependent on coal (IEA 2008). Wind power technology was developed and deployed initially in developed countries, but wide scale diffusion and rapid commercialization has been largely a result of the involvement of companies in China and India. The diffusion of wind energy has contributed to development by creating jobs, improving the local environment, and contributing to energy security.

Domestic policy supports for wind can be classified into three types: 1) those that help to reduce risks and create a stable market for wind energy, 2) those that help to reduce capital costs, and 3) those that help to reduce operating costs. The principal policy instruments for creating a stable market have been "feed-in tariffs" and "renewable portfolio standards" (RPS). Feed-in tariffs, along with long-term purchase commitments, can play an important role in reducing risks for investors. These policies, however, increase the weighted costs for electric utilities because wind power is more expensive than coal-based power and more difficult to integrate into the grid due to its intermittency. The policy instruments for reducing capital costs have included capital subsidies, grants, excise benefits, and tax credits. The policy supports for reducing operating costs have mainly involved favorable tax treatment to electricity generated from wind (e.g., lower sales tax). China and India have employed all three sets of policies within their countries (REN21 2005) involving considerable financial commitments (Peidong et al. 2009). However, these domestic policy supports have not only resulted in creating a domestic capacity but also a strong manufacturing capability within these countries. 
Local manufacturing has been found to be beneficial for the wider diffusion of wind, though is not a precondition for diffusion (Lewis and Wiser 2007). The positive aspects of local manufacturing can include reduced costs in some circumstances (Zhang et al. 2009; Lewis and Wiser 2007), technological risk reduction (Zhang et al. 2009), and private sector capacitybuilding, which is essential for developing public-private partnerships. Public-private partnerships played an important role in the success of wind power in Spain (Dinica 2008). In the cases of the United States, China, and India where we are witnessing a rapid growth in wind capacities (REN21 2009), we are also witnessing a creation of local manufacturing, which is not only catering to domestic demand but also to the international market. Lewis and Wiser (2007) indicate that there are different models for localization starting with assembly of imported components, then manufacturing of components, and finally full manufacturing of turbines. Countries can adapt a model based on their starting endowments and comparative strengths, which continue to change with wider diffusion of the technology.

International support for wind energy projects has happened through technology transfer including joint wind assessments, wind policy and program best practices information, joint wind turbine testing activities, and commercial wind development and financing partnerships and through carbon financing by participating in the CDM. The CDM revenues are a significant incentive for installing wind turbines (Zhang et al. 2009).

\subsubsection{Discussion}

The successful diffusion of wind energy has happened in part because of national policies that reduced market risks, technology risks, capital costs, operating costs, and improved local capabilities. These policies required substantial financial commitments from the countries themselves besides international support. Developing countries support technologies that can aid development as well as contribute to GHG mitigation. The idea of TNA is to identify such technologies and prepare an action plan for accelerated development, demonstration, and diffusion. The technology development and demonstration are covered in previous sections; in the case of diffusion, a broad portfolio of measures involves:

1. Changing policies to alter market design (e.g., feed-in tariffs require a change in the structure of electricity markets to enable wind producers to supply to the grids).

2. Improving the dissemination of information regarding technologies (e.g., wind assessments help identify potential sites for investors).

3. Creating associated infrastructures (e.g., absorbing wind power, which is an intermittent source of electricity, requires investments into storage or back up capacities).

4. Providing financial incentives for technologies until economies of scale and scope can bring down costs (e.g., capital subsidies and tax benefits allow investors to make their projects bankable).

5. Removing policies that exacerbate price distortions or favor incumbent technologies (e.g., removing fossil fuel subsidies; enforcing stricter environmental regulations to account for environmental externalities).

6. Creating policies that increase demand for cleaner technologies (e.g., RPSs require utilities to provide clean energy). 
7. Developing local manufacturing to improve local capacities and reduce costs (e.g., local manufacturing of wind turbines).

8. Collaborating internationally (discussed next).

\subsection{International Collaboration for National Sectoral Deployment and Diffusion Programs}

\subsubsection{Role of Sectoral Programs}

Enhancing the capacity of public institutions, governmental agencies, and private sector actors for initiating concrete actions in specific sectors is an important aspect of creating enabling environments in developing countries for a wider scale deployment of climate change technologies. Developing the capacity to undertake integrated and coordinated national plans targeting various sectors is particularly relevant since it allows for effective planning and ensures a greater possibility for achieving end results (IPCC 2000).

The adoption of relevant sectoral efforts needs to be aligned with non-climate-change-related national priorities and aspirations in an integrated manner, with the relevant sectors addressed (Heller and Shukla 2003). For example, technology deployment initiatives in the energy sector should be complementary to national objectives for industrial and economic development, energy infrastructure planning, and social and environmental aspects. Incorporating these considerations into a coherent plan and implementation program therefore requires the capacity to manage and integrate a variety of diverse considerations. In addition, an understanding of the technological and financial viability of specific technologies, as well as the associated market characteristics, is required. Careful attention also needs to be directed towards including relevant actors and stakeholders in the process. The capacity to address the issue in a coordinated manner is necessary, in order to handle the complexities associated with an aspiration to accelerate the deployment and diffusion of technologies in a developing country context. However, since the concern here is the accelerated diffusion of existing or emerging technologies, the barriers relating to the adoption of technologies at a later stage of the innovation cycle needs to be well understood. Barriers may also pertain to the specific sectors under consideration and these need to be addressed as well.

Technology transfer through the public and private sector may play a central role for supporting national sectoral efforts for climate change mitigation and adaptation. The transfer process may be implemented through financial and technical assistance and collaboration programs to developing countries or through support for partnerships and diffusion of technologies in the private sector (WTO 2009; UNEP 2009). Different types of bilateral and multilateral international cooperative initiatives aiming to enhance the capacity of national entities in developing countries to increase technology adoption may therefore be relevant.

\subsubsection{Cogen Program}

A long-term agreement between the European Union (EU) and the Association of Southeast Asian Nations (ASEAN) dating back to 1980 was established with the aim to increase economic cooperation between these regions. Within this overall framework, the EU-ASEAN Cogen program was completed in three phases in the period from 1991 to 2004, with the purpose of facilitating an enhanced adoption and diffusion of proven cogeneration technologies from Europe into ASEAN countries (European Commission 2006). As such, the program provides an 
appropriate and successful example of an international cooperative initiative with the objective of continuing to increase the adoption of low carbon technologies in the energy sector of certain developing countries.

As a central element, the objective of the EU-ASEAN Cogen program was to develop the national planning capacity to adopt similar sectoral initiatives through the provision of technical assistance to relevant institutions in the process of implementing the program. It also aimed at facilitating and providing business opportunities for the private sector companies in both regions to engage in technology transfer activities (COWI 2006). The program focused particularly on implementation of cogeneration technologies in the ASEAN wood and agro-industries, utilizing biomass residues from these industries in order to substitute fossil fuel consumption in their energy consuming processes.

The first phase of the program (1991-1994) concerned a technically focused identification phase for what was to become Cogen phase II. It aimed at increasing the awareness of European technologies in the ASEAN market and providing information to European suppliers for the opportunities in the Southeast Asian region. The first phase, however, also succeeded in implementing seven demonstration projects, although of a rather limited capacity, the maximum being $2.5 \mathrm{MWe}$.

The second phase (1995-1998) focused on the completion of 16 full-scale demonstration projects promoting further reference projects with a total capacity of $354 \mathrm{MWth} / 74 \mathrm{MWe}$ and a total investment of around 60 million Euros. Nine projects with a maximum capacity of $10 \mathrm{MWe}$ each were implemented throughout this phase and the purpose was to demonstrate the technical reliability, economic viability, and environmental benign effects of these projects. The Cogen program coordinating team worked as a business facilitator in this second phase and thereby laid the ground for an accelerated dissemination of biomass-cogeneration technologies in Cogen phase III through already established company relations.

The purpose of the third phase (2002-2004) was to secure further deployment of these technologies and demonstrate the ability to replicate such initiatives in the countries hosting the projects. In ASEAN countries such as Malaysia, Thailand, and Indonesia, eight additional projects were implemented in different industries during the third phase, most of these with a higher capacity than the earlier projects. Training and capacity building of representatives from private companies and governmental agencies was a central aspect in the third phase. To this end, a number of seminars, conferences, matchmaking events, site visits, and individual consultations were provided by the Cogen coordinating team. Strategic management tools and models for the purpose of coordinating efficient implementation of future projects were also introduced during these events.

\subsubsection{Discussion}

The Cogen example shows how the enabling environment and the capacity for deployment of climate change mitigation technologies in specific sectors has been enhanced through an internationally coordinated technology transfer initiative. Furthermore, an important achievement of the Cogen program was the awareness raised in certain industries, which potentially could adopt the technologies in their internal production processes. In the years following the completion of the Cogen program, some of the ASEAN countries also experienced an increase in 
biomass cogeneration projects implemented under the Clean Development Mechanism (UNEP 2009). This may, to some extent, be attributable to the importance given throughout the Cogen project of securing a long-term replication potential of cogeneration technologies in the region. Valuable insights therefore accrue from the Cogen program with regard to adoption of future strategies and programs consistent with implementation frameworks proposed under the UNFCCC negotiation process.

Technology support from developed countries as an element underlying developing countries' adoption of sector targeted nationally appropriate mitigation actions may be addressed through a staged approach similar (although preferably faster) to the Cogen project. This may involve elements to enhance the capacity of domestic entities in developing countries to coordinate and establish integrated plans for sector specific mitigation actions through focused technology deployment schemes. If implemented as complete and large-scale packages, such internationally coordinated deployment programs could involve elements of business training, demonstration, private sector partnerships, financing assistance, policy development, joint standards agreements, and best practice information exchange. For example, discussions concerning a comprehensive bilateral joint clean technology initiative between the United States and China have incorporated these elements, including common technology deployment road maps and marketing needs. Especially relevant in this regard are the implementation oriented approaches covering sector and technology specific mandates on short- or medium-term deployment of energy efficiency, renewable energy, clean transport, and other technologies (van Tilburg et al. 2009). Similarly, the possible expansion of the carbon market to include sectoral crediting mechanisms may also integrate some of these elements as aspects of larger bilateral or multilateral initiatives internationally governed by a UNFCCC body.

Furthermore, within an overall multilateral financial and governance structure under a possible UNFCCC technology institution, the proposed regional centers of excellence may also incorporate technology diffusion windows that target specific technological areas in developing countries (Tomlinson et al. 2008). As in the Cogen project, the enabling environment of host countries would thereby increase in terms of the capacity to generate and implement national sectoral diffusion and deployment programs. Large scale international technology diffusion and deployment programs should particularly promote the establishment of business relationships between technology suppliers, consultants, end users, and other private sector actors in order to support this objective. Therefore, facilitating a process whereby the engagement and involvement of relevant private sector companies is leveraged will be a central aspect for achieving end results.

\subsection{Intellectual Property Issues \\ 4.3.1 Intellectual Property Overview}

The UNFCCC (Article 4.5) requires developed countries take appropriate action for transfer of environmentally friendly technologies, including financial know-how and access to developing countries. This has been reiterated at various COP sessions as well. A substantive step in access to finance for technology transfer was taken by establishment of the GEF as the financial mechanism, who have since provided more than $\$ 2.5$ billion for transfer of environmentally friendly technologies to more than 50 developing countries. Though GEF and the subsequently created market mechanisms under the Kyoto Protocol, particularly the CDM, have fostered technology transfer to developing countries, the pace and the scale is nowhere near what would 
be required to address the issue of climate change. A related issue is that most of the technology transfer in such cases has been for technology deployment, bypassing the crucial element of technology development, which can spur innovations in developing countries as well. However, several bilateral and donor funded programs have helped technology development in developing countries. Commercial transactions involving the private sector have also helped technology transfer to developing countries, which included the transfer of environmentally friendly technologies (e.g., wind and solar energy technologies). Ockwell et al. (2009) conclude that existing policy mechanisms fail to consider the importance of developing indigenous capacity for technology expansion, which is essential even for diffusion of a technology. Technology development capacity is also important for the adoption of technologies to the country circumstances and needs. For developing countries, adoption, adaption, and development of environmentally sound technologies in line with their needs is important for their sustainable economic development. Often, large project-based approaches focus on the transfer of the hardware aspects of clean technologies, neglecting the crucial aspect of the transfer of underlying knowledge (know-how and know-why) and tacit knowledge. This can even undermine the performance of the technology so transferred, as some developing countries have experienced in the case of wind turbines where they have to depend on a technology supplier for repairs.

Intellectual Property Rights (IPR) has emerged as a contentious issue in technology transfer discussions, with differing views between developed and developing countries. IPRs refer to legal rights over ideas, creative processes, and products and include copyrights, trademarks, and patents. These patents have been the most powerful tools for holders to prevent the unauthorized use of their technological innovations. The research on empirical effects of IPRs on technology transfer to developing countries is inconclusive, with divergent views and results coming out from the studies. In addition, the studies previously conducted have, to a limited extent, specifically addressed the subject of climate change related technologies. Based on the empirical studies undertaken thus far, proponents of the strict IPR regime and developed countries claim that IPR reduces transaction costs for technology transfer through a regulatory framework, and it is a lack of IPR law or its enforcement that constitutes a main barrier to technology transfer. This line of reasoning also emphasizes the positive role that IPR plays with regard to development and diffusion of new technologies. IPRs are considered a catalyst that facilitates businesses to invest in risky ventures, giving them legal clarity and certainty. It is also reflected in one of the TRIPS rationales that the protection and enforcement of IPRs will contribute to both increased FDI and the transfer and dissemination of technology (UNCTAD-ICTSD 2003). The commentators on the other side consider this as protectionism on behalf of powerful western economies. Trade surpluses on license fees and royalties on patents of some developed countries are cited as an evidence as well as incentive for them to push for stricter IPR regime in developing countries. These commentators assert that low carbon technologies should be treated as public goods as they contribute to mitigation of future carbon emissions, and therefore, an international fund should be established to buy IPRs for these technologies to make them freely available to developing countries.

\subsubsection{Examples on IPR}

Interesting case studies are cited by commentators from both sides to support their arguments. See Box 1 for the case study of India and China that concludes that IPRs do not seem to prohibit access by developing country firms to the low carbon technologies. See Box 2 for the case study 
of South Korea which concludes that IPR can be a hindrance to technology transfer, especially if the "one size fits all" approach is used.

\section{Box 1. Indian and Chinese Experience: IPRs are not a Barrier}

Barton (2007) examined technology transfer for solar PV, wind, and biofuels, and Lewis and Wiser (2007) covered wind power industry in China and India in detail. Ockwell et al. (2007; 2008) covered a few case studies related to integrated gasification combined cycle (IGCC) for power generation, LED lighting, hybrid vehicles, biomass generation, and improving the combustion efficiency of existing power stations. Ockwell summarizes these and other studies and concludes that developing country firms had access to all the technologies examined, except that IGCC and hybrid vehicles in India were still at the R\&D stage and primarily seemed to be driven by indigenous R\&D. Access to wind technologies in India and China had been facilitated via the acquisition of licenses from developed country firms and, in the case of India, also by strategic acquisition of developed country firms. In the case of solar PV, China has pursued a strong policy of indigenous technology development, whereas India's access has principally been via a joint venture with BP Solar. For biofuels, significant indigenous ethanol industries in China, India, Pakistan, Japan, Thailand, and Malaysia exist with notable success of Brazil in this sector. The developing country firms however had no access to the most cutting edge technologies. To some extent Suzlon, India's most successful wind technology manufacturer with the fifth biggest share of the global market, has overcome these issues by buying majority shares in developed country firms in order to gain access to cutting edge technologies. This would seem to suggest that IPR may not be an issue in access to technologies by developing countries though may prohibit access to cutting edge technologies. 
Box 2: Korean Experience: IPRs are a Barrier

The Korean experience suggests that the effects of IPRs on technology transfer and local innovation in developing countries vary according to countries' levels of economic development and to the technological nature of economic activities and that these countries can reap long-term benefits from strong IPRs only after they reach a certain threshold level in their industrialization (Kim 2003). Kim concludes that strong IPRs would prevent developing countries from attempting industrialization at the very early stage. Examples of Korea and Taiwan, who first acquired and assimilated mature technologies to undertake duplicative imitation of existing foreign products with their skilled but cheap labor force, are given. This supplemented learning by doing and upgrading the quality of educational systems in Korea. The learning at this stage thus takes place through reverse engineering and duplicative imitation of mature foreign products. Kim argues that only after countries have built up science and technology infrastructure and accumulated indigenous capabilities to undertake creative imitation does IPR protection become an important element in technology transfer and industrial activities. He also suggests that Japan, Korea, and Taiwan could not have achieved their current levels of technological sophistication if strong IPR regimes had been forced on them during the early stage of their industrialization. He also argues that this applies to the United States and western Europe during their industrial revolutions. As a corollary to this, Kim suggests that differentiation in terms of the level of economic development and industrial sectors should be considered in the IPR protection and enforcement. Absorptive capacity of the developing countries also needs to be strengthened for a long-term solution.

In yet another example, Magic (2003) gives the example of Thailand, where despite tightening the IPR regime through patent acts, the technology transfer failed to foster growth in domestic technology R\&D. One of the reasons cited is "turnkey" projects where technology is imported and controlled by foreign experts for a limited purpose.

\subsubsection{Discussion}

The discussion regarding how best to handle IPR continues. Exchanging information and learning from common experiences on this topic could speed technology transfer. Addressing IPR must be combined with increasing educational and research infrastructures in developing countries and identifying and removing other barriers to technology transfer. Together, these measures will increase the absorptive capacity within these countries, although it may take time for results to be apparent.

IPR does not act as a barrier to the same extent for all countries. For developing countries with large domestic markets (emerging economies), IPR may not be a significant barrier, since technology transfer already occurs to some extent through FDI, licensing, and "outsourcing" knowledge. Access to cutting-edge, low carbon technologies continues to be a problem in these emerging economies, however. For the least developed countries, IPR is still a hindrance, though views on the significance of this issue differ. There is little dispute, however, that there is a need for a multifold increase in the transfer of environmentally friendly technologies between NorthSouth and South-South countries, including an increased capacity for technology development within country borders. These needs can be partly addressed through initiatives such as the Carbon Trust's proposed network of Low Carbon Technology Innovation and Diffusion Centres, Fundacion Chile (a not-for-profit organization geared towards facilitating access to relevant 
international innovations and increasing indigenous innovation capabilities), and the Eco-Patent Commons, in which member companies make patents that directly or indirectly improve or protect the environment available to anyone for use free of charge. 


\section{Options for Financing Clean Technology}

\subsection{What the Financing Infrastructure Should Do}

The financing challenge is often pictured as a gap in investment. The challenge is phrased, for example, as "we need to generate US $\$ 500$ billion additional investment into clean energy, annually up to 2030." The analysis then continues in a manner as if the international community should provide such finance, that this finance needs to be "leveraged" by public funding, and that international mechanisms or a fund can make this happen.

In reality, the challenge is of a wholly different nature. The clean energy investment gap (not to be confused with the incremental cost gap) is built up of a rich and heterogeneous set of investment gaps. Rather than leveraging capital for clean energy projects, the challenge consists mostly of diverting capital from high carbon energy investments to low carbon projects, and mobilizing additional capital. In addition, enabling environments for finance and investments are important. It is therefore not correct to talk of a "gap," since the difference between desired and baseline financing is only part of the investment challenge.

The financing challenge is also highly heterogeneous. In least-developed countries (high-risk environment, unstable regime, moderate growth), it is of a different nature than in emerging economies (stable regime, strong growth; opportunities but also regulatory risks) and developed countries (stable regime, low growth). Those making decisions on which projects to invest in are not only interested in returns, but they think in terms of risks. An investment is often

"structured": part of the investment is financed with low-risk debt finance and part with high-risk capital, so the whole of the investment has a certain average risk profile. This means that not only the projects and operational environment vary greatly, but also the investment itself can be broken up into parts.

Hence, there is no one-size-fits-all solution for financing clean technology. The heterogeneity of the challenge calls upon the participation of a multitude of institutions, including domestic institutions that take into account national sovereignty and international institutions that adhere to general rules of accountability. The institutions adhere to the characteristics of "measurability, reportability, and verifiability". Some institutions are already operational at a small scale, while others will have to be formed. The section below provides strategies for expanding and creating some of the most promising "no-regret" options for closing the clean energy investment gap.

\subsection{Components of a Financing Infrastructure}

\subsubsection{Investment Matchmaking and Advisory Services}

Investment matchmaking and advisory services bring together different actors involved in the low carbon technology market and provide assistance and advice for project developers and innovators by attracting investment and finance for their innovations. These services can make a positive impact because the various actors have different viewpoints that often inhibit spontaneous collaboration:

- Large, commercial banks based in developed countries are interested in investing in developing countries but are accustomed to a certain level of documentation and information on specific conditions and on market stability. Local conditions in developing countries are often well known with local banks and institutions but not well-documented. 
- Policymakers tend to think in terms of incremental costs and how to subsidize them. They are often not familiar with the considerations of financiers. They are often unaware of the barriers they themselves form for project developers and financiers (e.g. rapid policy changes, red tape, and changing political preferences).

- Innovators and project developers are often focused on their project or product and oblivious of contextual factors, demands of investors, and regulatory barriers. What an innovator considers a good business plan is often very different from what a potential financier would consider a bankable project.

Clearly, an essential element of estimating the risk of an investment decision involves sharing information across different actors. This information enables the variety of stakeholders to relate to each other and collaborate. Matchmaking events, where the actors have the opportunity to meet, in combination with capacity development, are also important.

National and regional matchmaking events aimed at overcoming information barriers between project developers and banks, banks and policymakers, innovators and banks, and local banks and international commercial banks could fill a need for interaction. In addition, assistance for innovators in writing business plans that are attractive to banks would be useful. Services would need to be tailored to the context, and it is therefore advisable that such services are implemented in the countries where the technology is to be implemented. Other elements could include:

- Finance training for policymakers.

- Energy training for financiers.

- Education for financial advisors and national matchmakers who are essential for catalyzing finance for diffusing and transferring technologies.

- Formation of national or regional innovation hubs/centers

The current Private Financing Advisory Network (PFAN) is an institution that aims to resolve some of the issues identified here. Founded in 2007, its experiences are relatively short-term but could be replicated to a larger scale by opening more regional offices and potentially combining them with other mechanisms such as a network of innovation centers (see Chapter 3).

Table 6. Possible Features of an Investment Matchmaking and Advisory Service

\begin{tabular}{|l|l|}
\hline Goals & $\begin{array}{l}\text { To overcome information barriers for investing in clean energy } \\
\text { technologies between different stakeholders. }\end{array}$ \\
& $\bullet \quad$ To facilitate clean energy investments. \\
\hline Participants & $\bullet \quad$ National governments. \\
& $\bullet \quad \begin{array}{l}\text { Commercial and local banks. } \\
\end{array}$ \\
\hline
\end{tabular}




\begin{tabular}{|c|c|}
\hline Scope of Activities & $\begin{array}{l}\text { - } \quad \text { Matchmaking events between innovators and financiers. } \\
\text { - } \quad \text { Training and education for all participants. } \\
\text { - } \quad \text { Assistance with business plans for innovators. } \\
\text { - } \quad \text { Case studies of best practices and financing information portals. }\end{array}$ \\
\hline $\begin{array}{l}\text { Selected Current } \\
\text { Examples }\end{array}$ & $\begin{array}{l}\text { - Private Financing Advisory Network (PFAN; } \underline{\text { http://www.climatetech.net/). }} \text {. } \\
\text { - Elements of Botswana Innovation Hub (http://www.bih.co.bw). }\end{array}$ \\
\hline Resource Levels & $\begin{array}{l}\text { - Roughly on the order of US } \$ 30-50 \text { million annually. Cost estimates } \\
\text { include } 80-100 \text { specialized staff and non-personnel costs (van Tilburg et } \\
\text { al. 2009). }\end{array}$ \\
\hline Benefits & $\begin{array}{l}\text { - Improved understanding of financing with policymakers and innovators. } \\
\text { - Improved understanding of local conditions with international banks. } \\
\text { - Overcome information barriers. } \\
\text { - Facilitated clean energy investments. }\end{array}$ \\
\hline $\begin{array}{l}\text { Constraints \& } \\
\text { Strategies }\end{array}$ & $\begin{array}{l}\text { - Country-level, tailor-made infrastructure makes coordination challenging } \\
\text { and implementation diffuse. } \\
\text { - Information is unlikely to be the only barrier. For reaching a significant } \\
\text { scale, it needs to be implemented in conjunction with other instruments. }\end{array}$ \\
\hline
\end{tabular}

\subsubsection{Coordination of Existing Funds}

Currently a large collective of development banks, official development assistance, trust funds, and carbon markets are already operational. Coordination between those efforts is limited. It is difficult to get a consistent overview of the type of support provided and the conditions for financing. The World Bank (excluding GEF and carbon finance) invested US $\$ 2.28$ billion in renewable energy and energy efficiency, but data on other banks and sources are not so clear. In 2008, the Group of Eight established the Climate Investment Funds, which is projected to result in US\$6.1 billion being invested in technologies for mitigation and adaptation in 2009-2012 (UNFCCC 2008c). It is difficult to gather information from non-governmental funding recipients. In addition, it is unclear how much those existing instruments currently invest in energy-related projects and programs that actually increase greenhouse gas emissions. The latter might be larger than the investments made in low carbon solutions.

Coordination of such funds can make a difference, particularly in the least-developed countries where they constitute a large share of foreign direct investment (UNFCCC 2008d). Funds could collaborate in making their investments more specific and complementary. They could assist each other in identifying appropriate projects and hence operate more efficiently.

Coordination could be centralized in the UNFCCC or in a more generic (not-climate-changespecific) UN body. 
Table 7. Possible Features of Existing Fund Coordination

\begin{tabular}{|c|c|}
\hline Goals & $\begin{array}{l}\text { - To improve efficiency in international fund operation. } \\
\text { - To decrease high carbon and increase low carbon investments. }\end{array}$ \\
\hline Participants & $\begin{array}{ll}\text { - } & \text { International banks. } \\
\text { - } & \text { Donor governments. }\end{array}$ \\
\hline $\begin{array}{l}\text { Scope of } \\
\text { Activities }\end{array}$ & $\begin{array}{l}\text { - } \quad \text { Exchange information and data. } \\
\text { - } \quad \text { Create low carbon standards for investments. }\end{array}$ \\
\hline Resource Levels & - Unclear, but likely to be limited. \\
\hline Benefits & $\begin{array}{l}\text { - Moved from high carbon to low carbon investments in countries where there } \\
\text { was a scope. }\end{array}$ \\
\hline $\begin{array}{l}\text { Constraints \& } \\
\text { Strategies }\end{array}$ & $\begin{array}{l}\text { - Coordination may be difficult, and the right body to coordinate may be hard to } \\
\text { find. } \\
\text { - Move to low carbon investment should not go at the expense of poverty } \\
\text { reduction activities. }\end{array}$ \\
\hline
\end{tabular}

\subsubsection{Investment Risk Mitigation Vehicles}

The traditional approach to stimulating low carbon technologies in developing countries is to somehow fund the incremental cost gap, for instance through a feed-in subsidy for the incremental electricity cost or covering the costs per tonne of $\mathrm{CO}_{2}$-eq avoided, such as in the CDM. More recently, there have been several suggestions for funds to cover the investment gap rather than the incremental cost gap and emphasize bringing down risks for investors (UNEP 2009; WEF 2009). Such risk mitigation vehicles need to be tailor-made for the specific problems that projects face. The risk mitigation measures vary the most across the major stages in the innovation chain, i.e., the demonstration phase versus the deployment or diffusion phases (van Tilburg et al. 2009; UNFCCC 2008c; Tomlinson, Zorlu, and Langley 2008; Tirpak and Stales 2008).

Several barriers prevent investors from diverting funds from conventional to low carbon energy options and particularly low carbon technologies in developing countries. UNEP (2009) reviews the barriers from a financial perspective and arrives at country politics risk, low carbon policy risk, currency risk, availability of projects, and increased overall risk because of the difficulty in evaluating a multitude of risks. In addition to those barriers, others can be identified, such as project execution risks (e.g., poor management and project delays), technological risks (because experience with the technology is limited), lack of infrastructure or human capacity, and information barriers (UNFCCC 2008c).

Funds for low carbon projects could be secured from institutions like Development Finance Institutions (such as the World Bank or the regional development banks) but also from pension funds. Together, for such institutions, the total investment size required does not seem to be the problem - the question is how to make the investments acceptable and attractive for those players. 
The multitude of barriers makes the design of an institutional arrangement for mitigating these risks complex as well. It is clear that several vehicles for mitigating risks need to be used to enable projects. A number of proposals include:

- Country and Low Carbon Policy Risk Fund. Investors can secure coverage for country risk in specific developing countries before raising capital, reducing the finance risk. This could be expanded with coverage of low carbon policy risk, as climate and energy policies sometimes change over time, resulting in higher investment uncertainty (WEF 2009).

- Loan Guarantees and Equity Subordination. Public investors take a subordinated position in equity financing, meaning that they will not receive pay-back until private investors have their returns (UNEP 2009; UNFCCC 2008c).

- Venture Capital Fund. High-risk public equity fund for pre-determined technologies beyond demonstration technology deployment in new environments (Tirpak and Stales 2008; UNFCCC 2008c).

Table 8. Possible Features of Investment Risk Mitigation Vehicles

\begin{tabular}{|c|c|}
\hline Goals & $\begin{array}{l}\text { To allow financiers to lower the risks on the high-risk part of their } \\
\text { investment, making financing low carbon technologies more attractive. }\end{array}$ \\
\hline Participants & $\begin{array}{l}\text { - Government/public entities. } \\
\text { - Financiers and investors such as pension funds and other institutional } \\
\text { investors. } \\
\text { - Development Finance Institutions. }\end{array}$ \\
\hline Scope of Activities & $\begin{array}{l}\text { - Provide loans against, with the possibility of non-payback, to cover the } \\
\text { high-risk part of the investment. } \\
\text { - Provide funds for country risk, currency risk, and low carbon policy risk. } \\
\text { - Provide funding for developing low carbon projects into bankable projects. } \\
\text { - Deploy venture capital for beyond-demonstration technology in new } \\
\text { environments. }\end{array}$ \\
\hline Resource Levels & - No estimate of resources required could be found. \\
\hline Benefits & $\begin{array}{l}\text { - } \text { Diverted and mobilized investments in low carbon technologies. } \\
\text { - Responsive to investor community. }\end{array}$ \\
\hline $\begin{array}{l}\text { Constraints \& } \\
\text { Strategies }\end{array}$ & $\begin{array}{l}\text { - Raising the public finance for the vehicles might not be straightforward. } \\
\text { - Experience is currently limited and will need to be gained. Trying many } \\
\text { different tracks at the same time would allow for learning. }\end{array}$ \\
\hline
\end{tabular}




\subsection{Implementation and Institutional Arrangements for Facilitating Low Carbon Technology Investment}

This section provides a scope of the implementation steps for the options to mobilize finance of low carbon technologies. Three generic options are identified: investment matchmaking and advisory services, coordination of existing funds, and investment risk mitigation vehicles.

Given the relevance of national circumstances, it seems that an international organization would not have to implement the aims of matchmaking. Rather, countries could set up national innovation hubs, potentially with international support from a "Network of Innovation Centres," mandated with the task of investment matchmaking. We suggest including matchmaking and advisory services in the mandate of such a network, which means that suitable personnel need to be hired.

Coordination of existing funds could be centralized in the UNFCCC or in another (not necessarily climate change-specific) international body such as the World Bank. Provision of information could be implemented by a public body such as UNEP Collaborating Centre on financing sustainable energy. ${ }^{3}$ In all cases, a decision in the climate negotiations, or bilateral funding through UNEP donations, would be needed for this aspect to materialize.

The implementation of investment risk mitigation vehicles is challenging, since the amount of the funding involved is large and the risk that public entities would need to take are significant. Still, there are a number of existing vehicles that can be used as starting points and that can then be expanded and given new mandates. WEF (2009) also suggests promoting dialogue between public and private investors so their interests can be further aligned - setting this up is step 2, which can potentially be undertaken by UNEP SEFI or its Finance Initiative. Such a platform or dialogue can inform further steps. Once experiences have been evaluated and sufficient confidence in specific vehicles has been gained, larger such funds could be accommodated under the UNFCCC and possibly administered by development finance institutions or even specific governments. This option should also be linked to the coordination of funds.

\footnotetext{
${ }^{3}$ The model that is an example here is the provision of CDM market information by UNEP/Risoe.
} 


\section{Conclusion}

This paper synthesizes information and studies of current and potential implementation approaches for enhancing international cooperation on clean energy technology $\mathrm{R} \& \mathrm{D}$, enabling environment, and financing in support of the objectives of the UNFCCC. Several conclusions can be drawn from this analysis of current and potential future programs that can inform design of future clean energy technology cooperation initiatives under the UNFCCC.

The Copenhagen Accord has set the rough form for the future global regime for addressing climate change. Continuing and building on the momentum of current efforts is important to the advancement of the development and diffusion of clean energy technologies. Specifically, investigating which approaches work best under which circumstances will advance implementation of the Accord. In the current environment, countries and international organizations may be best served by applying pragmatic approaches that enhance collaboration through existing bilateral and multilateral partnerships and demonstrate a commitment to rapid scaling up of technology cooperation and financing.

This paper highlights the fact that such programs will be most effective if they 1) focus on well defined and broadly endorsed national priorities, 2) strengthen developing country capacity and enabling environments, 3) apply a comprehensive approach at sufficient scale over multiple years, 4) build long-term public and private partnerships, 5) engage countries from all regions and promote broad knowledge sharing, and 6) coordinate and harmonize international support.

More detailed conclusions are presented for each of the three areas covered in this paper:

\subsection{R\&D Cooperation}

- $\quad R \& D$ Cooperation May be Most Effectively Implemented by Technology Networks. Networks comprised of representatives from developing and developed country research institutes, government research programs, and the private sector may be best positioned to implement specific R\&D projects. Such networks can directly engage practitioners to ensure that the work has a concrete and practical focus, building meaningful long-term partnerships, and complementing activities supported by national governments and the private sector.

- Address Needs to Build R\&D Capabilities in Least-Developed and Developing Countries. It is important to realize that networks should have meat on their bones-a network alone is not enough. R\&D institutions in developed countries often have sufficient capabilities to be part of an international network, but universities and research institutions in least-developed countries will need much assistance with capacity building. Networks and other international R\&D cooperation initiatives will be most effective where they provide assistance for such science and technology capacity building programs in developing countries.

- A Clean Energy Technology Advisory Group and Implementing Agencies Can Guide the Work of these Networks. An advisory group of clean energy experts from developing and developed countries can establish an overall clean energy R\&D plan and principles to guide work by the implementing agencies. The implementing agencies can be drawn largely from existing international energy agencies and 
partnerships (e.g., IEA, MEF energy technology partnerships, IPEEC, and IRENA) as well as the GEF, MDBs, and UN agencies. They can be assigned responsibility for managing specific elements of the international clean energy technology cooperation portfolio.

- Shared R\&D Technology Roadmaps Can Drive Program Design. One of the first tasks of these technology networks could be the establishment of common technology roadmaps to develop a shared vision for clean energy technology R\&D goals, barriers, and programs at global and regional levels (complementing national and private sector efforts) to achieve these goals. These roadmaps can provide a multiyear vision and provide the foundation for coordinated national, regional, and global R\&D initiatives. International review processes can be established to assess progress at global and regional levels relative to roadmap goals and to update the roadmaps.

- Multilateral R\&D Projects Can be Conducted both through Partnering on Independently Funded Projects and through Joint Solicitations. Multilateral R\&D projects can be driven by promoting teaming of interested research institutes (and companies) who have funding from their own independent sources and by pooling resources through common $R \& D$ solicitations. The technology networks can determine the most effective means of cooperation for a specific topic.

- Technology Demonstration Partnerships can be Implemented in Parallel with Expanding Demonstrations in Developing Countries. Efforts are needed to both expand partnerships in implementing demonstrations of emerging technologies and to expand support for demonstrations of more mature and emerging technologies (where appropriate) in developing countries. Such partnerships should include governments, the private sector, and international organizations.

\subsection{Enabling Environments}

- Strong National Policies are Essential for Diffusion of Technologies. National policies and measures play a key role in creating enabling environments in developing countries for an accelerated diffusion and uptake of clean energy technologies. However the enabling environment for cleaner technologies involves policies that reduce risks, remove distortions, and provide incentives. All this will, however, carry costs, and the countries will go forward only with the technologies that are aligned to their national priorities, which may relate to energy access, energy security, and economic, social, and environmental concerns. Capacity building efforts for national policymaking should keep in mind this concern. The TNA exercise is trying to address this by following a bottom-up process with explicit recognition of the national context and national priorities for identification of technological options. TNA could appropriately be implemented as a key element of developing countries' NAMAs.

- Launch Large Scale and Internationally Coordinated Programs Targeting Specific Sectors. Internationally coordinated large-scale programs targeting technology deployment in specific sectors in developing countries could be promoted and initiated either bilaterally or multilaterally. Such programs should be implemented as complete and comprehensive packages laying out a clear medium-term pathway for increasing technology diffusion and deployment. They could include technological and financial assistance in order to achieve well functioning implementation of viable technologies. 
Technological support could include training in operation and maintenance, system integration assistance, introduction of monitoring and auditing systems, management tools, and more. Projects within these programs should receive financial support and could function as showcases with a large replication potential in the national or regional context. Besides project finance, programs could also facilitate business and industry matchmaking, project inspection and supervision, and consultancy services.

- Access to Technology can be Addressed through Expanding Successful Technology Cooperation Models and Building Developing Country Capacity. Developed and developing countries have differing views regarding the impact of IPR on technology transfer. Identifying common experiences and successful case studies could provide insight needed to remove barriers and build new programs that improve educational and research infrastructures and increase the absorptive capacity of cutting edge climate technologies in developing countries. Recent, existing initiatives such as the Carbon Trust's proposed network of Low Carbon Technology Innovation and Diffusion Centres, Fundacion Chile, and the Eco-Patent Commons should also be strengthened and enlarged.

\subsection{Financing}

- Finance and Technology need to be Addressed in Combination. Technological development and transfer needs financing, and the type of financing depends on the technology and application. The separation of the topics of technology and financing in negotiations is an artificial one that could lead to inconsistencies. Some finance instruments may work for some technologies and not for others; their applicability depends, in part, on the stage of technological maturity, the scale of the technology, and the degree capital intensity.

- Learn Before Deployment. Current experience helps identify technological financing mechanisms that work on a particular scale and context. Lessons from existing financing activities can inform the design of larger financing instruments and help tailor them to a country's national policy and market conditions. It may make sense to start with an experimental phase for new financial instruments and then scale-up and expand to other country contexts.

- One Technology Fund is Unlikely to be Manageable. Although providing technology funding through a single, centralized fund (even one that is sub-divided) has the benefit of straight-forward institutional arrangements, this approach also has significant disadvantages. These include challenging governance structures, a reduced ability to learn from mistakes, and a higher degree of bureaucracy. A collection of funds and instruments, perhaps distributed across different countries, might help to overcome these disadvantages.

- Focus Public Finance Instruments on Risk, not on Incremental Costs. Funding risk mitigation vehicles is a more cost-effective way to use public financing instruments. This will not be sufficient for all technologies, because some technologies need incremental cost funding. However, there are a substantial number that could potentially benefit from such instruments. This approach would build confidence between parties, assuming the programs are credibly deployed. 


\section{References}

Barton, J.H. (2007). Intellectual Property and Access to Clean Technologies in Developing Countries: An Analysis of Solar Photovoltaic, Biofuel and Wind Technologies. Geneva, Switzerland: ICTSD.

Baumert, K.; Herzog, T.; Pershing, J. (2009). Navigating the Numbers: Greenhouse Gas Data and International Climate Policy. World Resources Institute. pdf.wri.org/navigating numbers.pdf Accessed June 28, 2010.

COWI. (September 2006). Ex-Post Evaluation of the COGEN 3 Programme. Framework Contract 2006/115686. Lyngby, Denmark:

COWI.http://www.deltha.ec.europa.eu/Publications/COGEN3\%20Popular\%20Report.pdf

Dinica, V. (2008). "Initiating a Sustained Diffusion of Wind Power: The Role of Public-Private Partnerships in Spain." Energy Policy (36) pp. 3562-3571.

EGTT. (June 1-10, 2009). "Strategy Paper for the Long-Term Perspective Beyond 2012, Including Sectoral Approaches, to Facilitate the Development, Deployment, Diffusion and Transfer of Technologies under the Convention." Prepared for the Thirtieth Session, Subsidiary Body for Scientific and Technological Advice by the Expert Group on Technology Transfer. Bonn, Germany: UNFCCC.

European Commission. (2006). Replicable \& Sustainable COGEN 3: Cogen Experience Overview. European Commission (EC) and ASEAN Centre for Energy (ACE). www.cogen3.net/final/docs/ceo_final.pdf Accessed June 28, 2010.

Gerstetter, C.; Marcellino, D. (November 2009). "The Current Proposals on the Transfer of Climate Technology in the International Climate Negotiations: An Assessment." Washington D.C.: Ecologic Institutehttp://ecologic.eu/download/projekte/82008249/8208/DDCF_Master_161109.pdf. Accessed June 21, 2010.

Heller, T.C.; Shukla, P.R. (2003). "Development and Climate: Engaging the Developing Countries." Beyond Kyoto: Advancing the International Effort Against Climate Change. Arlington, VA: Pew Center on Global Climate Change. http://www.pewcenteronthestates.org/uploadedFiles/wwwpewtrustsorg/Reports/Global_warming /PCGC_international_climate_efforts_1204.pdf Accessed June 28, 2010.

Hoekman, B.M.; Maskus, K.E.; Saggi, K. (2005). "Transfer of Technology to Developing Countries: Unilateral and Multilateral Policy Options." World Development (33:10) 1587-1602.

ICTSD-UNCTAD. (2003). Intellectual Property Rights, Implications for Development. Policy Discussion Paper; Intellectual Property Rights \& Sustainable Development Series, 152 pp.

IEA. (2008). Energy Technology Perspectives 2008: Scenarios and Strategies to 2050. International Energy Agency. ISBN 978-92-64-04142-4. 
IPCC. (2000). "Methodological and Technological Issues in Technology Transfer." A special report of the Intergovernmental Panel on Climate Change (IPCC), Working Group III.

Cambridge, MA: Cambridge University Press.

Kim, Linsu. (2003). Technology Transfer and Intellectual Property Rights: The Korean Experience. UNCTAD-ICTSD Project on IPRs and Sustainable Development, Issue Paper No. 2. June 2003.

Kline, D.; Vimmerstedt, L.; Benioff, R. (2003). “Clean Energy Technology Transfer: A Review of Programs under the UNFCCC."

http://www.springerlink.com/content/h5282185458725k8/fulltext.pdf. Accessed June 28, 2010.

Lewis, J.I.; Wiser, R.H. (2007). "Fostering a Renewable Energy Technology Industry: An International Comparison of Wind Industry Policy Support Mechanisms." Energy Policy (35) 1844-1857.

Magic, P. (2003). "International Technology Transfer \& Intellectual Property

Rights.”http://www.cs.utexas.edu/ fussell/courses/econtech/public-finalpapers/Peter_Magic International_IP Rights.pdf. Accessed June 21, 2010.

Ockwell, D.; Watson, J.; MacKerron, G.; Pal, P.; Yamin, F. (November 2008). "Key Policy Considerations for Facilitating Low Carbon Technology Transfer to Developing Countries." Energy Policy Vol 36, Issue 11, pages 4104-4115.

Ockwell, D.; Watson, J.; MacKerron, G.; Pal, P.; Yamin, F; Vasudevan, N.; Mohanty, P. (March 2007). UK-India Collaboration to Identify the Barriers to the Transfer of Low Carbon Energy

Technology. Report by SPRU, TERI, and IDS. http://www.sussex.ac.uk/sussexenergygroup/1-29.html. Accessed June 21, 2010.

Ockwell, D. et al. (2010), "Enhancing Developing Country Access to Eco-Innovation: The Case of Technology Transfer and Climate Change in a Post-2012 Policy Framework", OECD Environment Working Papers, No. 12, OECD Publishing. www.oecd.org/dataoecd/32/46/45263722.pdf Accessed: June 25, 2010.

OECD/IEA. (2009). How the Energy Sector can Deliver on a Climate Agreement in Copenhagen. Special Excerpt of the World Energy Outlook 2009 for the Bangkok UNFCCC meeting.

Olsen, K.H.; Fenhann, J.; Hinostroza, M. (2009). "Editorial." NAMAs and the Carbon Market: Nationally Appropriate Mitigation Actions of Developing Countries, Olsen, K.H., Fenhann, J., Hinostroza, M., eds. Roskilde, Denmark: UNEP Risoe Centre.

Peidong, Zhang, Yang Yanli, Shi jin, Zheng Yonghong, Wang Lisheng, and Li Xinrong. (2009). "Opportunities and challenges for renewable energy policy in China" Renewable and Sustainable Energy Reviews 13 pp.439-449.

REN21. (2005). Renewables 2005: Global Status Report. Paris: Renewable Energy Policy Network for 21st Century, REN21 Secretrait. 
REN21 (2009), Renewables Global Status Report: 2009 Update. Paris: Renewable Energy Policy Network for 21st Century, REN21 Secretrait.

Seres, S. (In consultation with Haites, E.). (December 2008). “Analysis of Technology Transfer in CDM Projects" Prepared for the UNFCCC Registration and Issuance Unit, CFM/SDM. http://cdm.unfccc.int/Reference/Reports/TTreport/TTrep08.pdf. Accessed June 21, 2010.

Tirpak, D.; Stales, B.C. (2008). Components of a New Financial Agreement. WRI, Washington DC.

Tomlinson, S.; Zorlu, P.; Langley, C. (November 2008). Innovation and Technology Transfer: Framework for a Global Climate Deal. London: E3G.

http://www.e3g.org/images/uploads/E3G_Innovation_and_Technology_Transfer_Full_Report.pd f. Accessed June 21, 2010.

UNDP. (September 2009). Handbook for Conducting Technology Needs Assessment for Climate Change. United Nations Development Programme, New York, NY.

http://www.preventionweb.net/english/professional/contacts/v.php?id=10 Accessed June 28, 2010.

UNEP. (October 2009). Catalysing Low-Carbon Growth in Developing Economies. UNEP and Partners. http://sefi.unep.org/fileadmin/media/sefi/docs/publications/PublicPrivateWeb.pdf. Accessed June 21, 2010.

UNFCCC. (2002). Decision 4/CP.7: Development and Transfer of Technologies.

FCCC/CP/2001/13/Add.1 http://unfccc.int/resource/docs/cop7/13a01.pdf\#page=22. Accessed June 21, 2010.

UNFCCC. (2008a). "Clean Development Mechanism 2008 in Brief." cdm.cchina.gov.cn/WebSite/CDM/UpFile/File2113.pdf

UNFCCC. (2008b). Decision 1/CP.13: Bali Action Plan. FCCC/CP/2007/6/Add.1. http://unfccc.int/resource/docs/2007/cop13/eng/06a01.pdf\#page=3. Accessed June 21, 2010.

UNFCCC. (2008c). Identifying, Analysing and Assessing Existing and Potential New Financing Resources and Relevant Vehicles to Support the Development, Deployment, Diffusion and Transfer of Environmentally Sound Technologies. FCCC/SB/2008/INF.7. Bonn, Germany: UNFCCC.

UNFCCC. (2008d). Investment and Financial Flows to Address Climate Change: An Update. FCCC/TP/2008/7. Bonn, Germany: UNFCCC.

van Tilburg, X.; Tomlinson, S.; De Vita, A.; Zorlu, P.; de Coninck, H. (2009). Financial Assessment of the Technology Proposals under the UNFCCC. ECN-E-09-073. Petten, Netherlands: Energy Research Centre of the Netherlands (ECN) and E3G. http://www.e3g.org/images/uploads/E3G ECN\%20Financial\%20Assessment\%20of\%20Technol ogy\%20Proposals\%20under\%20UNFCCC_October\%202009.pdf. Accessed June 21, 2010. 
WEF. (October 2009). Task Force on Low-Carbon Prosperity: Recommendations. Geneva, Switzerland: WEF.

http://www.weforum.org/documents/gov/Environment/TF\%20Low\%20Carbon\%20Prosperity\% 20Recommendations.pdf. Accessed June 21, 2010.

WTO. (November 24, 2009). "Standards and Safety: Technical Regulations and Standards." World Trade Organization

http://www.wto.org/english/thewto_e/whatis_e/tif_e/agrm4_e.htm\#TRS. Accessed June 21, 2010.

Zevallos, P. (2009). "The Trust Building Role of NAMAs." Olsen, K.H., Fenhann, J., Hinostroza, M., eds. NAMAs and the Carbon Market: Nationally Appropriate Mitigation Actions of Developing Countries Roskilde, Denmark: UNEP Risoe Centre.

Zhang, X.; Chang, S.; Huo, M.; Wang, R. (2009). "China's Wind Industry: Policy Lessons for Domestic Government Interventions and International Support." Climate Policy (9) 553-564. 


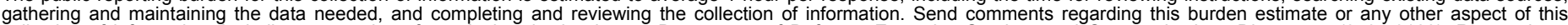

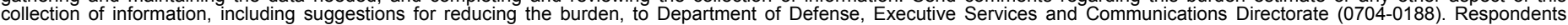

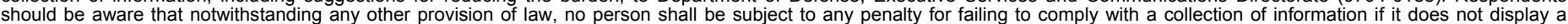

should be aware that notwithstanding

PLEASE DO NOT RETURN YOUR FORM TO THE ABOVE ORGANIZATION.
1. REPORT DATE (DD-MM-YYYY) August 2010
4. TITLE AND SUBTITLE
Strengthening Clean Energy Technology Cooperation Under the UNFCCC: Steps Toward Implementation

3. DATES COVERED (From - To)

5a. CONTRACT NUMBER

DE-AC36-08-GO28308

5b. GRANT NUMBER

5c. PROGRAM ELEMENT NUMBER

5d. PROJECT NUMBER

NREL/TP-6A0-48596

5e. TASK NUMBER

6A00.6003

5f. WORK UNIT NUMBER
7. PERFORMING ORGANIZATION NAME(S) AND ADDRESS(ES)

National Renewable Energy Laboratory

1617 Cole Blvd.

Golden, CO 80401-3393

\section{PERFORMING ORGANIZATION REPORT NUMBER \\ NREL/TP-6A0-48596}

9. SPONSORING/MONITORING AGENCY NAME(S) AND ADDRESS(ES)

\section{SPONSOR/MONITOR'S ACRONYM(S)} NREL

11. SPONSORING/MONITORING AGENCY REPORT NUMBER

12. DISTRIBUTION AVAILABILITY STATEMENT

National Technical Information Service

U.S. Department of Commerce

5285 Port Royal Road

Springfield, VA 22161

\section{SUPPLEMENTARY NOTES}

\section{ABSTRACT (Maximum 200 Words)}

Development of a comprehensive and effective global clean technology cooperation framework will require years of experimenting and evaluation with new instruments and institutional arrangements before it is clear what works on which scale and in which region or country. In presenting concrete examples, this paper aims to set the first step in that process by highlighting successful models and innovative approaches that can inform efforts to ramp up clean energy technology cooperation. This paper reviews current mechanisms and international frameworks for global cooperation on clean energy technologies, both within and outside of the UNFCCC, and provides selected concrete options for scaling up global cooperation on clean energy technology RD\&D, enabling environment, and financing.

\section{SUBJECT TERMS}

clean energy technology; CET; UNFCCC; RD\&D; international; greenhouse gas; GHG; deployment; enabling environment; finance; adaptation; energy efficiency; roadmap; renewable portfolio standards; RPS; feed-in tariffs; Cogen program; Intellectual Property Rights; IPR

\begin{tabular}{|l|l|l|l|l|}
\hline \multicolumn{3}{|l|}{ 16. SECURITY CLASSIFICATION OF: } & $\begin{array}{c}\text { 17. LIMITATION } \\
\text { OF ABSTRACT }\end{array}$ & $\begin{array}{c}\text { 18. NUMBER } \\
\text { OF PAGES }\end{array}$ \\
\hline $\begin{array}{l}\text { a. REPORT } \\
\text { Unclassified }\end{array}$ & $\begin{array}{c}\text { b. ABSTRACT } \\
\text { Unclassified }\end{array}$ & $\begin{array}{l}\text { c. THIS PAGE } \\
\text { Unclassified }\end{array}$ & UL & \\
\end{tabular}

19a. NAME OF RESPONSIBLE PERSON
19b. TELEPHONE NUMBER (Include area code)




\section{National Renewable Energy Laboratory}

1617 Cole Boulevard, Golden, Colorado 80401-3305

303-275-3000 • www.nrel.gov

NREL is a national laboratory of the U.S. Department of Energy Office of Energy Efficiency and Renewable Energy

Operated by the Alliance for Sustainable Energy, LLC

NREL/TP-6A0-48596・ August 2010

Printed with a renewable-source ink on paper containing at least

$50 \%$ wastepaper, including $10 \%$ post consumer waste. 